\title{
Lise Öğrencilerinin Din Kültürü ve Ahlak Bilgisi Programına Yönelik Tutumlarını Etkileyen Faktörler
}

\section{Factors Affecting Students Attitudes towards Religious Culture and Ethics Program}

\section{Fatih ÇAKMAK*}

\begin{abstract}
Received: 13 April 2018
Research Article

Accepted: 23 July 2018

ABSTRACT: Developments in science and technology are rapidly changing the structure of societies daily. As a result of these changes, human power is needed in different characteristics. For this reason, educational programs have to develop themselves in order to train the qualified individuals that society desires. The effort to keep pace with these changes makes it inevitable to create an open education system that allows them to follow innovations. Education is one of the institutions that guide the collecting. The effect of education on collecting influence and collective direction is primarily related to the preparation of educational programs in accordance with social expectations and the healthy process. The ability of the training programs to respond to community influences, direction and social needs requires the analysis of community needs. For effective religious instruction, it is necessary to identify student expectations in terms of community needs during the program development process. This research wants to answer this need. For this purpose, a scale was developed to determine the attitudes of high school students towards the Religious culture and ethics course lesson and program and the factors affecting these attitudes. Scale was applied and the obtained data were interpreted.
\end{abstract}

Keywords: education, religious education, program, student attitudes, factors affecting attitudes.

ÖZ: İnsan yaşamına yön veren bilim ve tekniğe ait gelişmeler toplumların yapısını her geçen gün hızla değiştirmektedir. Bu gelişmeler sonucunda farklı özellikte insan gücüne ihtiyaç duyulmaktadır. Eğitim programları da toplumların istediği nitelikteki bireyleri yetiştirmek için kendisini geliştirmek zorundadır. Bu değişimlere ayak uydurma çabası yenilikleri takip etme olanağı sağlayan ve gelişmelere açık bir eğitim sisteminin oluşturulmasını kaçınılmaz kılmaktadır. Eğitim topluma yön veren kurumlardan birisidir. Eğitimin topluma etkisi ve topluma yön verme derecesi, öncelikle eğitim programlarının toplumsal beklentilere uygun olarak hazırlanmasına ve sağlıklı işlemesine bağlıdır. Eğitim programlarının topluma etkisi, yön vermesi ve sosyal ihtiyaçlara cevap verebilmesi toplumun gereksinimlerinin analiz edilmesini gerektirir. Etkili bir din öğretimi için, program geliştirme sürecinde toplumun ihtiyacı bağlamında öğrenci beklentilerinin saptanması gerekmektedir. Araştırmada bu ihtiyaç tespit edilmek istenmektedir. Bu amaçla, lise öğrencilerinin Din Kültürü ve Ahlak Bilgisi dersine ve programına yönelik tutumlarını ve bu tutumları etkileyen faktörleri belirlemek için bir ölçek geliştirilmiştir. Ölçek uygulanmış, elde edilen veriler yorumlanmıştır.

Anahtar kelimeler: eğitim, din öğretimi, DKAB programı, öğrenci tutumları, tutumları etkileyen faktörler.

* Asst. Prof. Dr., Afyon Kocatepe University, Afyonkarahisar, Turkey, fcakmak@aku.edu.tr

Citation Information

Çakmak, F. (2018). Lise öğrencilerinin din kültürü ve ahlak bilgisi programına yönelik tutumlarını etkileyen faktörler. Kuramsal Eğitimbilim Dergisi [Journal of Theoretical Educational Science], 11(4), 1019-1069. 


\section{Giriş}

Eğitim, genel anlamda, bireyde davranış değiştirme süreci olarak tanımlanmaktadır (Ertürk, 1975). Eğitim sürecinde kişilerin davranışlarında meydana gelebilecek değişmelerin istenilen yönde olması beklenir (Demirel, Seferoğlu \& Yağc1, 2001). Davranış değişmelerinin istenilen yönde meydana gelmesini sağlamak için eğitimin, amaçlı ve planlı olması gerekir. Bu sebeple eğitim kurumsallaşmıştır. Eğitim kurumlarının belirlenen amaçları gerçekleştirmesinde; eğitim-öğretimi etkileyen ortak paydaşların katılımını sağlama önemli bir role sahiptir.

Eğitim topluma yön veren kurumlardan birisidir. Eğitimin topluma etkisi ve topluma yön verme derecesi, öncelikle eğitim programlarının toplumsal beklentilere uygun olarak hazırlanmasına ve sağlıklı işlemesine bağlıdır (Celep, Bülbül, \& Tunç, 2000). Eğitim programlarının topluma etkisi, yön vermesi ve sosyal ihtiyaçlara cevap verebilmesi toplumun gereksinimlerinin nicel ve nitel açıdan analiz edilmesini gerektirir. Eğitim programlarının sosyal beklentilere yönelik sağlıklı bir şekilde belirlenmesi ve işlemesi, eğitim kurumları ile toplumun örtüşen amaçları paylaşmalarıyla mümkündür.

Bilim ve teknolojideki gelişmeler toplumların yapısını her geçen gün hızla değiştirmektedir. $\mathrm{Bu}$ değişmeler sonucunda farklı özellikte insan gücüne ihtiyaç duyulmaktadır. $\mathrm{Bu}$ nedenle eğitim programları toplumların istediği nitelikteki bireyleri yetiştirmek için kendisini geliştirmek zorundadır. Bu değişimlere ayak uydurma çabası yenilikleri takip etme olanağı sağlayan ve gelişmelere açık bir eğitim sisteminin oluşturulmasını kaçınılmaz kılmaktadır (Uçar \& İpek, 2006).

Toplumsal kalkınmanın temelini eğitim oluşturmaktadır. Toplumda her alanda gerekli olan bilgi ve beceriyi eğitim sistemi yetiştirmekte ve geliştirmektedir. İnsan denilen varlığa şekil veren eğitimdir (Tandoğan, 2001). Bu bağlamda, eğitimden beklenen en önemli rol, eğitim programlarında yer alan istendik davranışları bireye kazandırmaktır. Eğitimin başarı ya da başarısızlığı, bu görevi yerine getirebilmesinin temel şartı, davranış kazandıracağı bireyi bedensel, zihinsel, toplumsal ve duygusal boyutlarıyla tanımaktır (Özdemir, 2000).

Öğretim programları geliştirilirken programın temel unsuru olarak öğrenenlerin ilgi ve ihtiyaçlarını belirlemek önemli bir aşamadır. Okullarda öğrencilerin ihtiyaçlarına, toplumun beklentilerine ve eğitim felsefesine uygun olarak hazırlanan programlar doğrultusunda öğretim yapılır ve öğrencilerde arzu edilen davranış değişikliği meydana getirilmeye çalışılır (Selçuk, 1998). Öğrenen merkezli bir öğretim anlayışında öğrenenin ilgi ve ihtiyaçları, öğretim programının amaçlarının belirlenmesinde, öğretimin içeriğinin düzenlenmesinde ve öğretim sürecini yapılandırmada merkezde yer alan bir faktördür. Öğrenenin merkezde yer alması, ülkemiz program geliştirme çalışmalarında da son on yıllarda giderek daha fazla dikkat edilen bir ilke olarak gözümüze çarpmaktadır (Altaş, 2008).

\section{Problem Durumu}

Bireyin gelişim özelliklerinin bilinmesi, ilgi ve ihtiyaçlarının saptanması, din öğretimi programlarından beklentilerinin belirlenmesi ve öğretimde uygulanması din eğitimi açısından önemli bir ihtiyaçtır. Etkili bir din öğretimi için, öğrenci merkezli 
öğrenme yaklaşımları çerçevesinde bireyin ilgi ve ihtiyaçlarına cevap verebilen bir din öğretimi verebilmek gerekmektedir.

$\mathrm{Bu}$ çerçevede araştırmamızın temel problemi şudur:

"Lise öğrencilerinin Din Kültürü ve Ahlak Bilgisi dersi programına karş1 tutumları nasıldır?" ve "bu tutumları etkileyen faktörler nelerdir?" sorularına cevap veren bir ölçek geliştirmek ve uygulamaktır.

$\mathrm{Bu}$ temel problem çerçevesinde araştırmamızın alt problemleri şunlardır:

Öğrencilerin cinsiyetlerine, yaşlarına, sınıflarına, hayatlarının büyük çoğunluğunu geçirdikleri yere ve dini yayınları takip etme durumuna göre;

1.Din Kültürü ve Ahlak Bilgisi dersine yönelik tutumları farklılaşmakta mıdır?

2.Ortaöğretim Din Kültürü ve Ahlak Bilgisi dersi programının yapısal özelliklerine yönelik tutumları farklılaşmakta mıdır?

3.Ortaögretim DKAB dersi programının temel ilkeleri ve hedefine yönelik tutumları farklılaşmakta mıdır?

4.Ortaöğretim DKAB dersi programının amacına, içeriğine ve uygulanmasına yönelik tutumları farklılaşmakta mıdır?

5.Öğrencilerin Ortaöğretim Din Kültürü ve Ahlak Bilgisi dersi programının yapısal özellikleri ile Din Kültürü ve Ahlak Bilgisi dersine yönelik tutumları arasında ilişki var mıdır?

6.Öğrencilerin Ortaöğretim Din Kültürü ve Ahlak Bilgisi dersi programının temel ilkeleri ve hedefleri ile Din Kültürü ve Ahlak Bilgisi dersine yönelik tutumları arasında ilişki var mıdır?

7. Öğrencilerin ortaöğretim $\mathrm{DKAB}$ dersi programının amacına, içeriğine ve uygulanması ile Din Kültürü ve Ahlak Bilgisi dersine yönelik tutumları arasında ilişki var midır?

8.Öğrencilerin Ortaöğretim Din Kültürü ve Ahlak Bilgisi dersi programının yapısal özellikleri ile öğrencilerin Ortaöğretim Din Kültürü ve Ahlak Bilgisi dersi programının temel ilkeleri ve hedeflerine yönelik tutumları arasında ilişki var mıdır?

9.Öğrencilerin Ortaöğretim Din Kültürü ve Ahlak Bilgisi dersi programının yapısal özellikleri ile öğrencilerin ortaöğretim DKAB dersi programının amacına, içeriğine ve uygulanmasına yönelik tutumları arasında ilişki var mıdır?

10.Öğrencilerin Ortaöğretim Din Kültürü ve Ahlak Bilgisi dersi programının temel ilkeleri ve hedefleri ile öğrencilerin ortaöğretim DKAB dersi programının amacına, içeriğgine ve uygulanmasına yönelik tutumları arasında ilişki var mıdır?

\section{Amaç ve Sinırlııklar}

Araştırmamızın temel amacı: Ortaöğretim DKAB program geliştirme sürecinde, öğrencilerin Din Kültürü ve Ahlak Bilgisi dersi programına karşı tutumlarını ve bu tutumları etkileyen faktörleri tespit ederek, değerlendirmektir.

$\mathrm{Bu}$ çerçevede araştırmanın alt amaçları da şunlardır:

Öğrencilerin cinsiyetlerine, yaşlarına, sınıflarına, hayatlarının büyük çoğunluğunu geçirdikleri yere ve dini yayınları takip etme durumuna göre; 
1.Din Kültürü ve Ahlak Bilgisi dersine karşı tutumlarını tespit ederek, değerlendirmektir.

2. Din Kültürü ve Ahlak Bilgisi dersi programının yapısal özelliklerine karşı tutumlarını tespit ederek, değerlendirmektir.

3. Ortaöğretim Din Kültürü ve Ahlak Bilgisi dersi programının temel ilkeleri ve hedeflerine yönelik tutumlarını tespit ederek, değerlendirmektir.

4.Ortaöğretim $\mathrm{DKAB}$ dersi programının amacına, içeriğine ve uygulanmasına yönelik tutumlarını tespit ederek, değerlendirmektir.

5.Öğrencilerin Ortaöğretim Din Kültürü ve Ahlak Bilgisi dersi programının yapısal özellikleri ile Din Kültürü ve Ahlak Bilgisi dersine yönelik tutumları arasında ilişki olup olmadığını belirlemektir.

6.Öğrencilerin Ortaöğretim Din Kültürü ve Ahlak Bilgisi dersi programının temel ilkeleri ve hedefleri ile Din Kültürü ve Ahlak Bilgisi dersine yönelik tutumları arasında ilişki olup olmadığını belirlemektir.

7.Öğrencilerin ortaöğretim DKAB dersi programının amacına, içeriğine ve uygulanması ile Din Kültürü ve Ahlak Bilgisi dersine yönelik tutumları arasında ilişki olup olmadığını belirlemektir.

8.Öğrencilerin Ortaöğretim Din Kültürü ve Ahlak Bilgisi dersi programının yapısal özellikleri ile öğrencilerin Ortaöğretim Din Kültürü ve Ahlak Bilgisi dersi programının temel ilkeleri ve hedeflerine yönelik tutumları arasında ilişki olup olmadığını belirlemektir.

9.Öğrencilerin Ortaöğretim Din Kültürü ve Ahlak Bilgisi dersi programının yapısal özellikleri ile öğrencilerin ortaöğretim DKAB dersi programının amacına, içeriğine ve uygulanmasına yönelik tutumları arasında ilişki olup olmadığını belirlemektir.

10.Öğrencilerin Ortaöğretim Din Kültürü ve Ahlak Bilgisi dersi programının temel ilkeleri ve hedefleri ile öğrencilerin ortaöğretim DKAB dersi programının amacına, içeriğine ve uygulanmasına yönelik tutumları arasında ilişki olup olmadığını belirlemektir.

Araştırmamızın temel sinırlılıkları şunlardır:

1-Araştırma öncesi belirlenen din dersine, programın yapısına ve programın yeterliliğine ilişkin tutumlara yönelik maddeler ile,

2-Ölçme aracının uygulandığı zaman dilimi ile,

3- Ölçme aracının uygulandığı yer olan Afyonkarahisar ilindeki ortaöğretim öğrencileri ile sinırlıdır.

\section{Yöntem}

Bu çalışmada; öğrencilerin, Din Kültür ve Ahlak Bilgisi dersine, Din Kültür ve Ahlak Bilgisi dersi programının yapısal özelliklerine, temel ilke ve hedeflerine, amacına, içeriğine ve uygulanmasına yönelik tutum düzeylerini tespit edebilmek, bu tutumların hangi faktörlere göre farklılaşıp, farklılaşmadıklarını belirleyebilmek amacıyla nicel araştırma yöntemi kullanılmıştır. Bu nedenle araştırma, "ilişkisel tarama modeline" (Karasar, 1998) uygundur. Bu tür modellerde ihtiyaç duyulan veriler, hedef kitle olarak tanımlanan çalışma evrenindeki birey ya da objelerden çeşitli araçlar 
kullanılarak toplanır. Soruna ilişkin mevcut durum herhangi bir müdahale olmaksızın betimlenmeye çalış1lır (Karasar, 1998).

Araştırma tek faktörlü bir desen (Balc1, 2001) olarak planlanmıştır. Ankette araştırmanın bağımlı değişkenleri; öğrencilerin Din Kültürü ve Ahlak Bilgisi dersine, Din Kültürü ve Ahlak Bilgisi dersi programının yapısal özelliklerine temel ilke ve hedeflerine, amacına, içeriğine ve uygulanmasına yönelik tutumları olarak belirlenmiştir. Bağımsız değişkenler ise; öğrencilerin cinsiyet, yaş, sınıf, hayatının büyük çoğunluğunu geçirdiği yer, din eğitimini nereden aldığı, dini yayınları takip etme durumudur.

Araştırmanın evrenini Türkiye genelinde bütün Ortaöğretim kurumlarında Din Kültürü ve Ahlak Bilgisi dersi öğrenimi gören öğrenciler oluşturmaktadır. Araştırmamızda bu evreni temsil edecek şekilde Afyonkarahisar ilindeki ortaöğretim öğrencilerinden 350 kişilik bir örneklem grubu nitelikli atama (amaçlı örnekleme) yöntemine (Balc1, 2001; Gökçe, 1988) göre seçilmiştir.

\section{Veri Toplama Araçları}

Öğrencilerin Din Kültürü ve Ahlak Bilgisi dersine yönelik tutumlarını belirlemek için hazırladığımız ölçek iki ana bölümden oluşmaktadır. Birinci bölümde öncelikle öğrencilerle ilgili kişisel bilgilere yer verilmiş sonra öğrencilerin DKAB dersine yönelik tutumları ölçülmüştür. Ölçeğin ikinci bölümünde öncelikle öğrencilerin DKAB dersi programının yapısına, temel ilkeleri ve hedefine, amacına, içeriğine ve uygulanmasına yönelik tutumları ölçülmüştür.

$\mathrm{Bu}$ araştırmada, güvenilirlik analizi yapılırken Cronbach's Alpha katsayısına bakılmıştır. Öğrencilerin DKAB dersine, DKAB dersi programının yapısına ve DKAB dersi programının temel ilke ve hedeflerine, DKAB dersi programının amaç, içerik ve uygulanmasına yönelik tutumlarını ölçtüğümüz ölçeğin geçerlik ve güvenirlik çalışmaları için ölçek, 200 lise öğrencisine uygulanmıştır. Ölçeğin güvenirlik testi sonucunda tüm sorular için elde edilen $\alpha$ değeri .953'dir. Bu sonuç $\alpha \geq .9$ olduğundan ölçeğin toplam güvenirliğinin mükemmel kategorisinde olduğunu göstermektedir.

\section{Verilerin Çözümlenmesi}

Öğrencilerin Din Kültürü ve Ahlak Bilgisi dersine, Din Kültürü ve Ahlak Bilgisi dersi programının yapısına, Din Kültürü ve Ahlak Bilgisi dersi programının temel ilkeleri ve hedefine, amacına, içeriğine ve uygulanmasına yönelik tutumlarının belirlenmesi ve bu düzeyleri etkileyen faktörlerin tespit edilmesini inceleyen bu araştırmada ölçme araçları ile öğrencilerden elde edilen verilerin çözümlenmesinde SPSS istatistik paket programı kullanılmıştır.

Öğrencilerin belirlenen katılım düzeyleri, puan toplamları kullanılarak değerlendirilmiştir. Bunun için her bir boyutta yer alan maddelere katılım düzeylerine ilişkin toplam puanlar hesaplanmış ve bu puanlar büyükten küçüğe doğru sıralanmıştır. Her bir katılım düzeyine ait toplam puanlar kullanılarak, ortaöğretim Din Kültürü ve Ahlak Bilgisi dersi alan öğrencilerin o katılıma hangi düzeyde sahip olduğu ölçek bazında değerlendirilmiştir.

“Öğrencilerin Din Kültürü ve Ahlak Bilgisi dersine”, "Din Kültürü ve Ahlak Bilgisi dersi programının yapısına", "Din Kültürü ve Ahlak Bilgisi dersi programının temel ilkeleri ve hedefine", "DKAB dersi programının amacına, içeriğine ve 
uygulanmasına" yönelik tutum ölçekleri ile tespit edilen tutum düzeylerinin değişkenlere göre farklılaşmalarını belirlemek için iki alt kategoriye sahip değişkenler için bağımsız örneklemler T-testi ve 2 den fazla alt kategoriye sahip değişkenler için "ANOVA testi” yapılmıştır. Analiz sonucu bir fark tespit edilmişse bu farkın kaynağını bulmak için grupların ortalama puanları arasında en düşük farkları belirleyebilmek için "TUKEY çoklu karşılaştırma testi kullanılmıştır. Ayrıca tutum ölçekleri arasında ilişki olup olmadığını test etmek amacıyla "Basit Korelasyon Analizi" uygulanmış, "Pearson Momentler Çarpımı Korelasyon Katsayısı" hesaplanmıştır. İstatistiksel analizlerde 0.5 anlamlılık düzeyi esas alınmıştır.

\section{Bulgular}

Ölçek geçerlik ve güvenirlik çalışmaları tamamlandıktan sonra Afyonkarahisar ilinde okul türüne göre; bir Fen lisesi, bir Anadolu Lisesi ve bir de Meslek lisesi olmak üzere 3 okulda $9,10,11$ ve 12. sinıflarda öğrenim görmekte olan 355 öğrenciye uygulanmış ve aşağıdaki sonuçlar elde edilmiştir.

\section{Ankete Katılanlar Hakkında Tanımlayıcı Bilgiler}

Araştırmamıza katılan öğrencilerin cinsiyet, yaş, sınıf, yaşamlarını geçirdikleri yer ve din eğitimlerini aldıkları kaynaklar ile ilgili bilgiler aşağıdaki gibidir.

Tablo 1

Araştırmaya Katılan Öğrencilerin Cinsiyetleri

\begin{tabular}{lcc}
\hline Cinsiyet & Kişi & Yüzde \% \\
\hline Kadın & 207 & 58.3 \\
Erkek & 148 & 41.7 \\
\hline Toplam & 355 & 100.00 \\
\hline
\end{tabular}

Tablo 2

Araştırmaya Katılan Öğrencilerin Yaşları

\begin{tabular}{lcc}
\hline Yaş & Kişi & $\%$ \\
\hline 14 & 14 & 3.9 \\
\hline 15 & 86 & 24.2 \\
\hline 16 & 176 & 49.6 \\
\hline 17 & 79 & 22.3 \\
\hline TOPLAM & 355 & 100.00 \\
\hline
\end{tabular}


Tablo 3

Araştırmaya Katılan Öğrencilerin Sınıfları

\begin{tabular}{lcc}
\hline Sinif & Kişi & $\%$ \\
\hline 9 & 54 & 15.2 \\
\hline 10 & 209 & 58.9 \\
\hline 11 & 86 & 24.2 \\
\hline 12 & 6 & 1.7 \\
\hline TOPLAM & 355 & 100.00 \\
\hline
\end{tabular}

Tablo 4

Araştırmaya Katılan Öğrencilerin Yaşamlarını Geçirdikleri Yer

\begin{tabular}{lcc}
\hline Yaşamınızı Geçirdiğiniz Yer & Kişi & $\%$ \\
\hline Köy & 14 & 3.9 \\
\hline Kasaba & 15 & 4.2 \\
\hline İlçe & 50 & 14.1 \\
\hline İl & 259 & 73.0 \\
\hline Büyük Şehir & 17 & 4.8 \\
\hline TOPLAM & 355 & 100.00 \\
\hline
\end{tabular}

Tablo 5

Araştırmacıların Din Eğitimlerini Aldıkları Kaynaklar

\begin{tabular}{lcc}
\hline \multirow{2}{*}{ Din Eğitimi Alınan Yer ${ }^{1}$} & \multicolumn{2}{c}{ Evet } \\
\cline { 2 - 3 } Aile & $\mathrm{n}$ & $\%$ \\
\hline Kur'an Kursu & 286 & 80.6 \\
\hline Din Kültürü ve Ahlak Bilgisi dersleri & 165 & 46.5 \\
\hline Kendi kendime & 155 & 43.7 \\
\hline Dini bilgim yok & 80 & 22.5 \\
\hline Diğer & 10 & 2.8 \\
\hline
\end{tabular}

\footnotetext{
${ }^{1}$ Birden fazla cevap vardır.
} 
Tablo 6

Araştırmacıların Dini Yayınları Takip Etme Durumu

\begin{tabular}{lcc}
\hline & \multicolumn{2}{c}{ Evet } \\
\cline { 2 - 3 } Din ile ilgili aşağıdaki yayınlardan hangisini okursunuz $^{1}$ & $\mathrm{n}$ & $\%$ \\
\hline Dini Kitap & 132 & 37.2 \\
\hline Hiçbiri & 132 & 37.2 \\
\hline İlmihal Kitapları & 85 & 23.9 \\
\hline Diğer & 32 & 9.0 \\
\hline Dini dergi & 21 & 5.9 \\
\hline Gazete & 19 & 5.4 \\
\hline
\end{tabular}

DKAB Dersi Programına Yönelik Tutumlar

Öğrencilerin cinsiyetleri ile tutumları arasındaki ilişki. Öğrencilerin cinsiyetleri ile tutumlar arasındaki ilişkileri gösteren tablolar aşağıdaki gibidir:

Tablo 7

DKAB Dersine Yönelik Tutumları İle Cinsiyetleri Arasındaki İlişki

\begin{tabular}{|c|c|c|c|c|c|c|}
\hline & & \multicolumn{5}{|c|}{ Levene's Test for Equality of Variances } \\
\hline & & $\mathrm{F}$ & Sig. & $\mathrm{t}$ & df & $\begin{array}{l}\text { Sig. (2- } \\
\text { tailed) }\end{array}$ \\
\hline \multirow[t]{2}{*}{$\begin{array}{l}\text { DKAB } \\
\text { dersine } \\
\text { yönelik tutum }\end{array}$} & $\begin{array}{l}\text { Equal } \\
\text { variances } \\
\text { assumed }\end{array}$ & 1.613 & .205 & -1.122 & 353 & .263 \\
\hline & $\begin{array}{l}\text { Equal } \\
\text { variances not } \\
\text { assumed }\end{array}$ & & & -1.109 & 302.392 & .268 \\
\hline
\end{tabular}

Öğrencilerin cinsiyetleri ile DKAB dersine yönelik tutumları arasında anlamlı bir ilişki yoktur.

Tablo 8

DKAB Dersi Programının Yapısına Yönelik Tutumları İle Cinsiyetleri Arasındaki İlişki

Levene's Test for Equality

of Variances

\begin{tabular}{llll}
\hline F & Sig. $\mathrm{t}$ df & $\begin{array}{l}\text { Sig. }(2- \\
\text { tailed) }\end{array}$
\end{tabular}

DKAB dersi programının

Equal variances

yapısına yönelik tutum

assumed

$\begin{array}{llll}4.428 & .036 & -.191 \quad 353\end{array}$

.848

Equal variances not

assumed

$\begin{array}{lll}-.186 & 285.690 \quad .852\end{array}$

${ }^{1}$ Birden fazla cevap vardır.

(C) 2018 AKU, Kuramsal Eğitimbilim Dergisi - Journal of Theoretical Educational Science, 11(4), 1019-1069 
Öğrencilerin cinsiyetleri ile DKAB dersi programının yapısına yönelik tutumları arasında anlamlı bir ilişki yoktur.

Tablo 9

DKAB Dersi Programının Temel İlke ve Hedeflerine Yönelik Tutumları İe Cinsiyetleri Arasındaki İlişki

\begin{tabular}{|c|c|c|c|c|c|c|}
\hline & & \multicolumn{5}{|c|}{ Levene's Test for Equality of Variances } \\
\hline & & $\mathrm{F}$ & Sig. & $\mathrm{t}$ & df & $\begin{array}{l}\text { Sig. (2- } \\
\text { tailed) }\end{array}$ \\
\hline \multirow{2}{*}{$\begin{array}{l}\text { DKAB dersi } \\
\text { programının } \\
\text { temel ilke ve } \\
\text { hedeflerine } \\
\text { yönelik tutum }\end{array}$} & $\begin{array}{l}\text { Equal } \\
\text { variances } \\
\text { assumed }\end{array}$ & 2.390 & .123 & -.456 & 353 & .649 \\
\hline & $\begin{array}{l}\text { Equal } \\
\text { variances } \\
\text { not assumed }\end{array}$ & & & -.447 & 293.857 & .655 \\
\hline
\end{tabular}

Öğrencilerin cinsiyetleri ile DKAB dersi programının temel ilke ve hedeflerine yönelik tutumları arasında anlamlı bir ilişki yoktur.

Tablo 10

DKAB Dersi Programının Temel İlke Ve Hedeflerine Yönelik Tutumları İle Cinsiyetleri Arasındaki İlişki

\begin{tabular}{|c|c|c|c|c|c|c|}
\hline & \multicolumn{6}{|c|}{ Levene's Test for Equality of Variances } \\
\hline & & $\mathrm{F}$ & Sig. & $\mathrm{t}$ & df & $\begin{array}{l}\text { Sig. (2- } \\
\text { tailed) }\end{array}$ \\
\hline \multirow{2}{*}{$\begin{array}{l}\text { DKAB dersi } \\
\text { programının } \\
\text { amacı. içerik ve } \\
\text { uygulanmasına } \\
\text { yönelik tutum }\end{array}$} & $\begin{array}{l}\text { Equal } \\
\text { variances } \\
\text { assumed }\end{array}$ & 2.390 & .123 & -.456 & 353 & .649 \\
\hline & $\begin{array}{l}\text { Equal } \\
\text { variances } \\
\text { not assumed }\end{array}$ & & & -.447 & 293.857 & .655 \\
\hline
\end{tabular}

Öğrencilerin cinsiyetleri ile DKAB dersi programının amacı, içerik ve uygulanmasına yönelik tutumları arasında anlamlı bir ilişki yoktur. Kaya'nın (2001) ilköğretim ve lise, Arıcı'nın (2008) ise ilköğretim 6. ve 7. sınıflar üzerinde yaptığı araştırmalarda cinsiyet değişkeni açısından öğrencilerin DKAB dersine yönelik tutumlarında anlamlı bir farklılık tespit edilmemiştir. Zengin' in (2013) ilk ve ortaöğretim düzeyinde yaptığı araştırmada ise cinsiyet değişken açısından anlamlı bir ilişki tespit edilmiştir. 
Öğrencilerin yaşları ile tutum puanları arasındaki ilişki. Öğrencilerin yaşları ile tutumlar arasındaki karşılaştırmayı gösteren tablolar aşağıdaki gibidir:

Tablo 11

DKAB Dersine Yönelik Tutumları İle Yaşları Arasındaki İlişki

\begin{tabular}{lllllll}
\hline & & $\begin{array}{l}\text { Sum of } \\
\text { Squares }\end{array}$ & df & Mean Square & F & Sig. \\
\hline & $\begin{array}{l}\text { Between } \\
\text { Groups }\end{array}$ & 22.623 & 3 & 7.541 & 8.848 & .000 \\
\cline { 2 - 6 } $\begin{array}{l}\text { DKAB dersine } \\
\text { yönelik tutum }\end{array}$ & $\begin{array}{l}\text { Within } \\
\text { Groups }\end{array}$ & 299.156 & 351 & .852 & \\
\cline { 2 - 6 } & Toplam & 321.778 & 354 & & \\
\hline
\end{tabular}

Öğrencilerin yaşları ile DKAB dersine yönelik tutumları arasında anlamlı bir ilişki vardır. Bu ilişkiyi gösteren tablo aşağıdaki gibidir:

Tablo 12

DKAB Dersine Yönelik Tutumları İle Yaşları Arasındaki İlişki

\begin{tabular}{|c|c|c|c|c|c|}
\hline $\begin{array}{l}\text { Bağımsız } \\
\text { değişken }\end{array}$ & (I) Yaşınız & (J) Yaşınız & $\begin{array}{c}\text { Mean } \\
\text { Difference (I-J) }\end{array}$ & Std. Error & Sig. \\
\hline \multirow{12}{*}{$\begin{array}{l}\text { DKAB dersine } \\
\text { yönelik tutum }\end{array}$} & \multirow{3}{*}{14} & 15 & -.40465 & .26606 & .426 \\
\hline & & 16 & -.41705 & .25636 & .365 \\
\hline & & 17 & .18354 & .26771 & .903 \\
\hline & \multirow{3}{*}{15} & 14 & .40465 & .26606 & .426 \\
\hline & & 16 & -.01239 & .12146 & 1.000 \\
\hline & & 17 & $.58820^{*}$ & .14387 & .000 \\
\hline & \multirow{3}{*}{16} & 14 & .41705 & .25636 & .365 \\
\hline & & 15 & .01239 & .12146 & 1.000 \\
\hline & & 17 & $.60059^{*}$ & .12502 & .000 \\
\hline & \multirow{3}{*}{17} & 14 & -.18354 & .26771 & .903 \\
\hline & & 15 & $-.58820^{*}$ & .14387 & .000 \\
\hline & & 16 & $-.60059^{*}$ & .12502 & .000 \\
\hline
\end{tabular}

Tablo incelendiğinde öğrencilerin 15 yaşındaki öğrencilerin DKAB dersine yönelik tutumlarının 17 yaşındaki öğrencilerden anlamlı bir şekilde yüksek olduğu görülmektedir. Yine tabloya bakıldığında, 16 yaşındaki öğrencilerin DKAB dersine yönelik tutumlarının 17 yaşındaki öğrencilerden anlamlı bir şekilde yükssek olduğu görülmektedir. Bu durum öğrencilerin ortaöğretim hayatının ilerleyen dönemlerinde DKAB dersine yönelik olumsuz bir algı geliştirdikleri şeklinde yorumlanabilir. Bunun sebepleri araştırılmalıdır. Ayrıca ortaya çıkan bu sonuç gençlerin dini bunalım ve 
şüpheler dönemini yoğun bir şekilde yaşadıkları bu dönemde kendilerine sağlıklı bir din eğitiminin yapılıp yapılmadığı sorusunu da gündeme getirebilir. Zira alınan din eğitiminin niteliği derse yönelik tutumlarını değiştirebilir.

Öğrencilerin yaşları ile DKAB dersi programının yapısına yönelik tutumlarının ilişkilendirilmesi aşağıdaki gibidir:

Tablo 13

DKAB Dersi Programının Yapısına Yönelik Tutumları İle Yaşları Arasındaki İlişki

\begin{tabular}{lllllll}
\hline & & $\begin{array}{l}\text { Sum of } \\
\text { Squares }\end{array}$ & df & $\begin{array}{l}\text { Mean } \\
\text { Square }\end{array}$ & F & Sig. \\
\hline \multirow{2}{*}{$\begin{array}{l}\text { DKAB dersi } \\
\text { programının } \\
\text { yapisina yönelik } \\
\text { tutum }\end{array}$} & $\begin{array}{l}\text { Between } \\
\text { Groups }\end{array}$ & 25.830 & 3 & 8.610 & 9.144 & .000 \\
\cline { 2 - 6 } & Within & 330.510 & 351 & .942 & \\
\cline { 2 - 6 } & Groups & 356.340 & 354 & & \\
\hline
\end{tabular}

Öğrencilerin yaşları ile DKAB dersi programının yapısına yönelik tutumları arasında anlamlı bir ilişki vardır. Bu ilişkiyi gösteren tablo aşağıdaki gibidir:

Tablo 14

DKAB Dersi Programının Yapısına Yönelik Tutumları İle Yaşları Arasındaki İlişki

\begin{tabular}{|c|c|c|c|c|c|}
\hline $\begin{array}{l}\text { Bağımsız } \\
\text { değiş̧ken }\end{array}$ & (I) Yaşınız & (J) Yaşınız & $\begin{array}{c}\text { Mean } \\
\text { Difference (I-J) }\end{array}$ & Std. Error & Sig. \\
\hline \multirow{12}{*}{$\begin{array}{l}\text { DKAB dersi } \\
\text { programının } \\
\text { yapısına yönelik } \\
\text { tutum }\end{array}$} & \multirow{3}{*}{14} & 15 & -.24121 & .27966 & .824 \\
\hline & & 16 & -.18555 & .26946 & .901 \\
\hline & & 17 & .44577 & .28139 & .389 \\
\hline & \multirow{3}{*}{15} & 14 & .24121 & .27966 & .824 \\
\hline & & 16 & .05566 & .12767 & .972 \\
\hline & & 17 & $.68698^{*}$ & .15122 & .000 \\
\hline & \multirow{3}{*}{16} & 14 & .18555 & .26946 & .901 \\
\hline & & 15 & -.05566 & .12767 & .972 \\
\hline & & 17 & $.63132^{*}$ & .13141 & .000 \\
\hline & \multirow{3}{*}{17} & 14 & -.44577 & .28139 & .389 \\
\hline & & 15 & $-.68698^{*}$ & .15122 & .000 \\
\hline & & 16 & $-.63132^{*}$ & .13141 & .000 \\
\hline
\end{tabular}

Tablo incelendiğinde öğrencilerin 15 yaşındaki öğrencilerin DKAB dersi programının yapısına yönelik tutumlarının 17 yaşındaki öğrencilerden anlamlı bir şekilde yüksek olduğu görülmektedir. Yine tabloya bakıldığında, 16 yaşındaki öğrencilerin DKAB dersi programının yapısına yönelik tutumlarının 17 yaşındaki öğrencilerden anlamlı bir şekilde yüksek olduğu görülmektedir. 
Öğrencilerin yaşları ile DKAB dersi programının temel ilke ve hedeflerine yönelik tutumlarının ilişkilendirilmesi aşağıdaki gibidir:

Tablo 15

DKAB Dersi Programının Temel Illke ve Hedeflerine Yönelik Tutumları İle Yaşları Arasındaki Illişki

\begin{tabular}{lllllll}
\hline & & $\begin{array}{l}\text { Sum of } \\
\text { Squares }\end{array}$ & df & $\begin{array}{l}\text { Mean } \\
\text { Square }\end{array}$ & F & Sig. \\
\hline \multirow{2}{*}{$\begin{array}{l}\text { DKAB dersi } \\
\text { programının } \\
\text { temel ilke ve } \\
\text { hedeflerine }\end{array}$} & $\begin{array}{l}\text { Between } \\
\text { Groups }\end{array}$ & 12.636 & 3 & 4.212 & 5.018 & .002 \\
\cline { 2 - 7 } & $\begin{array}{l}\text { Within } \\
\text { Groups }\end{array}$ & 294.616 & 351 & .839 & & \\
\cline { 2 - 7 } & Toplam & 307.252 & 354 & & & \\
\hline
\end{tabular}

Öğrencilerin yaşları ile DKAB dersi programının temel ilke ve hedeflerine yönelik tutumları arasında anlamlı bir ilişki vardır. Bu ilişkiyi gösteren tablo aşağıdaki gibidir:

Tablo 16

DKAB Dersi Programının Temel İlke ve Hedeflerine Yönelik Tutumları İle Yaşları Arasındaki İlişki

\begin{tabular}{|c|c|c|c|c|c|}
\hline $\begin{array}{l}\text { Bağımsız } \\
\text { değişken }\end{array}$ & (I) Yaşınız & (J) Yaşınız & $\begin{array}{c}\text { Mean } \\
\text { Difference (I-J) }\end{array}$ & Std. Error & Sig. \\
\hline \multirow{12}{*}{$\begin{array}{l}\text { DKAB dersi } \\
\text { programının } \\
\text { temel ilke ve } \\
\text { hedeflerine } \\
\text { yönelik tutum }\end{array}$} & \multirow{3}{*}{14} & 15 & -.16312 & .26403 & .926 \\
\hline & & 16 & -.13872 & .25441 & .948 \\
\hline & & 17 & .30850 & .26567 & .652 \\
\hline & \multirow{3}{*}{15} & 14 & .16312 & .26403 & .926 \\
\hline & & 16 & .02441 & .12054 & .997 \\
\hline & & 17 & $.47162^{*}$ & .14278 & .006 \\
\hline & \multirow{3}{*}{16} & 14 & .13872 & .25441 & .948 \\
\hline & & 15 & -.02441 & .12054 & .997 \\
\hline & & 17 & $.44722^{*}$ & .12407 & .002 \\
\hline & \multirow{3}{*}{17} & 14 & -.30850 & .26567 & .652 \\
\hline & & 15 & $-.47162^{*}$ & .14278 & .006 \\
\hline & & 16 & $-.44722^{*}$ & .12407 & .002 \\
\hline
\end{tabular}

Tablo incelendiğinde öğrencilerin 15 yaşındaki öğrencilerin DKAB dersi programının temel ilke ve hedeflerine yönelik tutumlarının 17 yaşındaki öğrencilerden anlamlı bir şekilde yüksek olduğu görülmektedir. Yine tabloya bakıldığında, 16 yaşındaki öğrencilerin $\mathrm{DKAB}$ dersi programının temel ilke ve hedeflerine yönelik 
tutumlarının 17 yaşındaki öğrencilerden anlamlı bir şekilde yüksek olduğu görülmektedir.

Öğrencilerin yaşları ile DKAB dersi programının amacı, içerik ve uygulanmasına yönelik tutumlarının ilişskilendirilmesi aşağıdaki gibidir:

\section{Tablo 17}

DKAB Dersi Programının Amacı, İçerik ve Uygulanmasına Yönelik Tutumları Ile Yaşları Arasındaki İlişki

\begin{tabular}{lllllll}
\hline & & $\begin{array}{l}\text { Sum of } \\
\text { Squares }\end{array}$ & df & $\begin{array}{l}\text { Mean } \\
\text { Square }\end{array}$ & F & Sig. \\
\hline $\begin{array}{l}\text { DKAB dersi } \\
\text { programının amac1. } \\
\begin{array}{l}\text { içerik ve } \\
\text { uygulanmasına } \\
\text { yönelik tutum }\end{array}\end{array}$ & $\begin{array}{l}\text { Between } \\
\text { Groups }\end{array}$ & 12.636 & 3 & 4.212 & 5.018 & .002 \\
\cline { 2 - 6 } & Within & 294.616 & 351 & .839 & \\
\hline
\end{tabular}

Öğrencilerin yaşları ile DKAB dersi programının amacı, içerik ve uygulanmasına yönelik tutumları arasında anlamlı bir ilişki vardır. Bu ilişkiyi gösteren tablo aşağıdaki gibidir:

Tablo 18

DKAB Dersi Programının Amacı, Içerik Ve Uygulanmasına Yönelik Tutumları İle Yaşları Arasındaki İlişki

\begin{tabular}{|c|c|c|c|c|c|}
\hline Bağımsız değişken & $\begin{array}{l}\text { (I) } \\
\text { Yaşınız }\end{array}$ & $\begin{array}{l}(\mathrm{J}) \\
\text { Yaşınız }\end{array}$ & $\begin{array}{l}\text { Mean } \\
\text { Difference (I-J) }\end{array}$ & $\begin{array}{l}\text { Std. } \\
\text { Error }\end{array}$ & Sig. \\
\hline \multirow{12}{*}{$\begin{array}{l}\text { DKAB dersi programının amacı. içerik ve } \\
\text { uygulanmasına yönelik tutum }\end{array}$} & \multirow{3}{*}{14} & 15 & -.16312 & .26403 & .926 \\
\hline & & 16 & -.13872 & .25441 & .948 \\
\hline & & 17 & .30850 & .26567 & .652 \\
\hline & \multirow{3}{*}{15} & 14 & .16312 & .26403 & .926 \\
\hline & & 16 & .02441 & .12054 & .997 \\
\hline & & 17 & $.47162^{*}$ & .14278 & .006 \\
\hline & \multirow{3}{*}{16} & 14 & .13872 & .25441 & .948 \\
\hline & & 15 & -.02441 & .12054 & .997 \\
\hline & & 17 & $.44722^{*}$ & .12407 & .002 \\
\hline & \multirow{3}{*}{17} & 14 & -.30850 & .26567 & .652 \\
\hline & & 15 & $-.47162^{*}$ & .14278 & .006 \\
\hline & & 16 & $-.44722^{*}$ & .12407 & .002 \\
\hline
\end{tabular}


Tablo incelendiğinde öğrencilerin 15 yaşındaki öğrencilerin DKAB dersi programının temel ilke ve hedeflerine yönelik tutumlarının 17 yaşındaki öğrencilerden anlamlı bir şekilde yüksek olduğu görülmektedir. Yine tabloya bakıldığında, 16 yaşındaki öğrencilerin DKAB dersi programının temel ilke ve hedeflerine yönelik tutumlarının 17 yaşındaki öğrencilerden anlamlı bir şekilde yüksek olduğu görülmektedir.

Öğrencilerin sınıfları ile tutum puanları arasındaki ilişki. Öğrencilerin sınıfları ile tutumlar arasındaki karşılaştırmayı gösteren tablolar aşağıdaki gibidir:

Tablo 19

DKAB Dersine Yönelik Tutumları İle Sınıfları Arasındaki İlişki

\begin{tabular}{lllllll}
\hline & & $\begin{array}{l}\text { Sum of } \\
\text { Squares }\end{array}$ & df & Mean Square & F & Sig. \\
\hline DKAB dersine & Between Groups & 40.038 & 3 & 13.346 & 16.627 & .000 \\
\cline { 2 - 7 } yönelik tutum & Within Groups & 281.741 & 351 & .803 & & \\
\cline { 2 - 7 } & Toplam & 321.778 & 354 & & \\
\hline
\end{tabular}

Öğrencilerin sınıfları ile DKAB dersine yönelik tutumları arasında anlamlı bir ilişki vardır. Bu ilişkiyi gösteren tablo aşağıdaki gibidir:

Tablo 20

DKAB Dersine Yönelik Tutumları İle Sınıfları Arasındaki İlişki

\begin{tabular}{|c|c|c|c|c|c|}
\hline Bağımsız değişken & $\begin{array}{l}\text { (I) } \\
\text { Sinıfinız }\end{array}$ & $\begin{array}{l}(\mathrm{J}) \\
\text { Sinıfinız }\end{array}$ & $\begin{array}{c}\text { Mean } \\
\text { Difference (I-J) }\end{array}$ & Std. Error & Sig. \\
\hline \multirow{12}{*}{ DKAB dersine yönelik tutum } & \multirow{3}{*}{9} & 10 & -.25389 & .13677 & .249 \\
\hline & & 11 & $.55418^{*}$ & .15556 & .002 \\
\hline & & 12 & .18519 & .38554 & .963 \\
\hline & \multirow{3}{*}{10} & 9 & .25389 & .13677 & .249 \\
\hline & & 11 & $.80807^{*}$ & .11478 & .000 \\
\hline & & 12 & .43907 & .37097 & .638 \\
\hline & \multirow{3}{*}{11} & 9 & $-.55418^{*}$ & .15556 & .002 \\
\hline & & 10 & $-.80807^{*}$ & .11478 & .000 \\
\hline & & 12 & -.36899 & .37830 & .764 \\
\hline & \multirow{3}{*}{12} & 9 & -.18519 & .38554 & .963 \\
\hline & & 10 & -.43907 & .37097 & .638 \\
\hline & & 11 & .36899 & .37830 & .764 \\
\hline
\end{tabular}

Tablo incelendiğinde 9. Sınıf öğrencilerin DKAB dersine yönelik tutumlarının 11. Sınıf öğrencilerinden anlamlı bir şekilde yüksek olduğu görülmektedir. Yine tabloya 
bakıldığında, 10. sınıf öğrencilerin DKAB dersine yönelik tutumlarının 11. sınıf öğrencilerden anlamlı bir şekilde yüksek olduğu görülmektedir.

Tablo 21

DKAB Dersi Programının Yapısına Yönelik Tutumları İle Sınıfları Arasındaki İlişki

\begin{tabular}{lllllll}
\hline & & $\begin{array}{l}\text { Sum of } \\
\text { Squares }\end{array}$ & df & $\begin{array}{l}\text { Mean } \\
\text { Square }\end{array}$ & F & Sig. \\
\hline & $\begin{array}{l}\text { Between } \\
\text { Groups }\end{array}$ & 46.935 & 3 & 15.645 & 17.748 & .000 \\
\cline { 2 - 7 } $\begin{array}{l}\text { DKAB dersi programının yapisina } \\
\text { yönelik tutum }\end{array}$ & $\begin{array}{l}\text { Within } \\
\text { Groups }\end{array}$ & 309.405 & 351 & .881 & & \\
& Toplam & 356.340 & 354 & \\
\hline
\end{tabular}

Öğrencilerin sınıfları ile DKAB dersi programının yapısına yönelik tutumları arasında anlamlı bir ilişki vardır. Bu ilişkiyi gösteren tablo aşağıdaki gibidir:

Tablo 22

DKAB Dersi Programının Yapısına Yönelik Tutumları İle Sınıfları Arasındaki İlişki

\begin{tabular}{|c|c|c|c|c|c|}
\hline $\begin{array}{l}\text { Bağımsız } \\
\text { değişken }\end{array}$ & $\begin{array}{l}\text { (I) } \\
\text { Sinıfinız }\end{array}$ & $\begin{array}{l}(\mathrm{J}) \\
\text { Sinıfinız }\end{array}$ & $\begin{array}{l}\text { Mean } \\
\text { Difference (I-J) }\end{array}$ & Std. Error & Sig. \\
\hline \multirow{12}{*}{$\begin{array}{l}\text { DKAB dersi } \\
\text { programının } \\
\text { yapısına yönelik } \\
\text { tutum }\end{array}$} & \multirow{3}{*}{9} & 10 & -.30827 & .14332 & .139 \\
\hline & & 11 & $.56798^{*}$ & .16302 & .003 \\
\hline & & 12 & -.11000 & .40403 & .993 \\
\hline & \multirow{3}{*}{10} & 9 & .30827 & .14332 & .139 \\
\hline & & 11 & $.87625^{*}$ & .12028 & .000 \\
\hline & & 12 & .19827 & .38876 & .957 \\
\hline & \multirow{3}{*}{11} & 9 & $-.56798^{*}$ & .16302 & .003 \\
\hline & & 10 & $-.87625^{*}$ & .12028 & .000 \\
\hline & & 12 & -.67798 & .39644 & .320 \\
\hline & \multirow{3}{*}{12} & 9 & .11000 & .40403 & .993 \\
\hline & & 10 & -.19827 & .38876 & .957 \\
\hline & & 11 & .67798 & .39644 & .320 \\
\hline
\end{tabular}

Tablo incelendiğinde 9. sınıf öğrencilerin DKAB ders programının yapısına yönelik tutumlarının 11. sınıf öğrencilerinden anlamlı bir şekilde yüksek olduğu görülmektedir. Yine tabloya bakıldığında, 10.sınıf öğrencilerin DKAB dersi programının yapısına yönelik tutumlarının 11. sınıf öğrencilerden anlamlı bir şekilde yüksek olduğu görülmektedir.

Öğrencilerin sınıfları ile DKAB dersi programının temel ilke ve hedeflerine yönelik tutumlarının ilişkilendirilmesi aşağıdaki gibidir: 
Tablo 23

DKAB Dersi Programının Temel İlke ve Hedeflerine Yönelik Tutumları İle Sinıfları Arasındaki İlişki

\begin{tabular}{lllllll}
\hline & & $\begin{array}{l}\text { Sum of } \\
\text { Squares }\end{array}$ & df & $\begin{array}{l}\text { Mean } \\
\text { Square }\end{array}$ & F & Sig. \\
\hline \multirow{2}{*}{$\begin{array}{l}\text { DKAB dersi } \\
\text { programinin } \\
\text { temel ilke ve } \\
\text { hedeflerine }\end{array}$} & $\begin{array}{l}\text { Between } \\
\text { Groups }\end{array}$ & 32.040 & 3 & 10.680 & 13.621 & .000 \\
\cline { 2 - 6 } & Within & 275.212 & 351 & .784 & \\
\cline { 2 - 6 } & Groups & 307.252 & 354 & & \\
\hline
\end{tabular}

Öğrencilerin sınıfları ile DKAB dersi programının temel ilke ve hedeflerine yönelik tutumları arasında anlamlı bir ilişki vardır. Bu ilişkiyi gösteren tablo aşağıdaki gibidir:

Tablo 24

DKAB Dersi Programının Temel Illke ve Hedeflerine Yönelik Tutumları İe Sinıfları Arasındaki İlişki

\begin{tabular}{|c|c|c|c|c|c|}
\hline $\begin{array}{l}\text { Bağımsız } \\
\text { değişken }\end{array}$ & $\begin{array}{l}\text { (I) } \\
\text { Sinıfinız }\end{array}$ & $\begin{array}{l}\text { (J) } \\
\text { Sinıfinız }\end{array}$ & $\begin{array}{l}\text { Mean } \\
\text { Difference (I-J) }\end{array}$ & Std. Error & Sig. \\
\hline \multirow{12}{*}{$\begin{array}{l}\text { DKAB dersi } \\
\text { programının } \\
\text { temel ilke ve } \\
\text { hedeflerine } \\
\text { yönelik tutum }\end{array}$} & \multirow{3}{*}{9} & 10 & -.30257 & .13517 & .115 \\
\hline & & 11 & $.41792^{*}$ & .15374 & .035 \\
\hline & & 12 & -.01852 & .38105 & 1.000 \\
\hline & \multirow{3}{*}{10} & 9 & .30257 & .13517 & .115 \\
\hline & & 11 & $.72049^{*}$ & .11344 & .000 \\
\hline & & 12 & .28405 & .36665 & .866 \\
\hline & \multirow{3}{*}{11} & 9 & $-.41792^{*}$ & .15374 & .035 \\
\hline & & 10 & $-.72049^{*}$ & .11344 & .000 \\
\hline & & 12 & -.43643 & .37389 & .648 \\
\hline & \multirow{3}{*}{12} & 9 & .01852 & .38105 & 1.000 \\
\hline & & 10 & -.28405 & .36665 & .866 \\
\hline & & 11 & .43643 & .37389 & .648 \\
\hline
\end{tabular}

Öğrencilerin sınıfları ile DKAB dersi programının amacı, içerik ve uygulanmasına yönelik tutumlarının ilişkilendirilmesi aşağıdaki gibidir: 
Tablo 25

DKAB Dersi Programının Amaç, Iç̧erik ve Uygulanmasına Yönelik Tutumları Ile Sınıfları Arasındaki İlişki

\begin{tabular}{lllllll}
\hline & & $\begin{array}{l}\text { Sum of } \\
\text { Squares }\end{array}$ & df & $\begin{array}{l}\text { Mean } \\
\text { Square }\end{array}$ & F & Sig. \\
\hline $\begin{array}{l}\text { DKAB dersi } \\
\text { programının amac1, } \\
\begin{array}{l}\text { içerik ve } \\
\text { uygulanmasına } \\
\text { yönelik tutum }\end{array}\end{array}$ & $\begin{array}{l}\text { Between } \\
\text { Groups }\end{array}$ & 32.040 & 3 & 10.680 & 13.621 & .000 \\
\cline { 2 - 7 } & Within & 275.212 & 351 & .784 & & \\
\cline { 2 - 5 } & Groups & 307.252 & 354 & & & \\
\hline
\end{tabular}

Öğrencilerin sınıfları ile DKAB dersi programının amacı, içerik ve uygulanmasına yönelik tutumları arasında anlamlı bir ilişki vardır. Bu ilişkiyi gösteren tablo aşağıdaki gibidir:

Tablo 26

DKAB Dersi Programının Amaç, Iç̧erik ve Uygulanmasına Yönelik Tutumları Ile Sınıfları Arasındaki İlişki

\begin{tabular}{|c|c|c|c|c|c|}
\hline Bağımsız değişken & $\begin{array}{l}\text { (I) } \\
\text { Sinıfinız }\end{array}$ & $\begin{array}{l}\text { (J) } \\
\text { Sinıfinız }\end{array}$ & $\begin{array}{l}\text { Mean } \\
\text { Difference (I-J) }\end{array}$ & Std. Error & Sig. \\
\hline \multirow{12}{*}{$\begin{array}{l}\text { DKAB dersi } \\
\text { programının amacı, } \\
\text { içerik ve } \\
\text { uygulanmasına } \\
\text { yönelik tutum }\end{array}$} & \multirow{3}{*}{9} & 10 & -.30257 & .13517 & .115 \\
\hline & & 11 & $.41792^{*}$ & .15374 & .035 \\
\hline & & 12 & -.01852 & .38105 & 1.000 \\
\hline & \multirow{3}{*}{10} & 9 & .30257 & .13517 & .115 \\
\hline & & 11 & $.72049^{*}$ & .11344 & .000 \\
\hline & & 12 & .28405 & .36665 & .866 \\
\hline & \multirow{3}{*}{11} & 9 & $-.41792^{*}$ & .15374 & .035 \\
\hline & & 10 & $-.72049^{*}$ & .11344 & .000 \\
\hline & & 12 & -.43643 & .37389 & .648 \\
\hline & \multirow{3}{*}{12} & 9 & .01852 & .38105 & 1.000 \\
\hline & & 10 & -.28405 & .36665 & .866 \\
\hline & & 11 & .43643 & .37389 & .648 \\
\hline
\end{tabular}

Tablo incelendiğinde 10. Sınıf öğrencilerin DKAB ders programının amac1, içerik ve uygulanmasına yönelik tutumlarının 11. Sınıf öğrencilerinden anlamlı bir şekilde yüksek olduğu görülmektedir. Kaya'nın (2001) araştırmasında da okul kademesine göre öğrencilerin DKAB dersine karşı tutumunda anlamlı farklılık tespit edilmiştir. Araştırmada ilköğretim öğrencilerinin DKAB dersine karşı tutumu ortaöğretim öğrencilerinden daha yüksektir. Zengin'in (2013) araştırmasında da 4.sınıf öğrencilerinin DKAB dersine yönelik tutumları daha yüksek iken, 12. sınıf öğrencilerin 
tutum puanları daha düşük çıkmıştır. $\mathrm{Bu}$ da bizim araştırmamızdaki yaş büyüdükçe öğrencilerin DKAB dersine yönelik tutum puanlarının azalması ile örtüşmektedir.

\section{Öğrencilerin hayatlarının büyük çoğunluğunu geçirdikleri yer ile tutum} puanları arasındaki ilişki. Öğrencilerin hayatlarının büyük çoğunluğunu geçirdikleri yer ile tutumlar arasındaki karşılaştırmayı gösteren tablolar aşağıdaki gibidir:

Tablo 27

DKAB Dersine Yönelik Tutumları İle Hayatlarının Büyük Çoğunluğunu Geçirdikleri Yer Arasindaki İlişki

\begin{tabular}{lllllll}
\hline & & $\begin{array}{l}\text { Sum of } \\
\text { Squares }\end{array}$ & df & Mean Square & F & Sig. \\
\hline \multirow{2}{*}{$\begin{array}{l}\text { DKAB dersine } \\
\text { yönelik tutum }\end{array}$} & $\begin{array}{l}\text { Between } \\
\text { Groups }\end{array}$ & 13.613 & 4 & 3.403 & 3.865 & .004 \\
\cline { 2 - 6 } & $\begin{array}{l}\text { Within } \\
\text { Groups }\end{array}$ & 308.165 & 350 & .880 & \\
\cline { 2 - 6 } & Toplam & 321.778 & 354 & & \\
\hline
\end{tabular}

Öğrencilerin hayatlarının büyük çoğunluğunu geçirdikleri yer ile DKAB dersine yönelik tutumları arasında anlamlı bir ilişki vardır. Bu ilişskiyi gösteren tablo aşağıdaki gibidir:

Tablo 28

DKAB Dersine Yönelik Tutumları İle Hayatlarının Büyük Çoğunluğunu Geçirdikleri Yer Arasındaki İlişki

\begin{tabular}{|c|c|c|c|c|c|}
\hline Bağımsız değişken & $\begin{array}{l}\text { (I) } \\
\text { Hayatlarının } \\
\text { büyük } \\
\text { çoğunluğunu } \\
\text { geçirdikleri } \\
\text { yer }\end{array}$ & $\begin{array}{l}(\mathrm{J}) \\
\text { Hayatlarının } \\
\text { büyük } \\
\text { çoğunluğunu } \\
\text { geçirdikleri } \\
\text { yer }\end{array}$ & $\begin{array}{l}\text { Mean } \\
\text { Difference (I-J) }\end{array}$ & Std. Error & Sig. \\
\hline \multirow{11}{*}{$\begin{array}{l}\text { DKAB dersine } \\
\text { yönelik tutum }\end{array}$} & \multirow{4}{*}{ Köy } & Kasaba & -.60571 & .34870 & .413 \\
\hline & & İlçe & .39829 & .28373 & .626 \\
\hline & & İl & .13436 & .25747 & .985 \\
\hline & & Büyük Şehir & .45546 & .33865 & .663 \\
\hline & \multirow{4}{*}{ Kasaba } & Köy & .60571 & .34870 & .413 \\
\hline & & İlçe & $1.00400^{*}$ & .27624 & .003 \\
\hline & & İl & $.74008^{*}$ & .24919 & .026 \\
\hline & & Büyük Şehir & $1.06118^{*}$ & .33240 & .013 \\
\hline & \multirow[b]{3}{*}{ İlçe } & Köy & -.39829 & .28373 & .626 \\
\hline & & Kasaba & $-1.00400^{*}$ & .27624 & .003 \\
\hline & & İl & -.26392 & .14494 & .363 \\
\hline
\end{tabular}




\begin{tabular}{|c|c|c|c|c|}
\hline \multirow{5}{*}{ İl } & Büyük Şehir & .05718 & .26344 & 1.000 \\
\hline & Köy & -.13436 & .25747 & .985 \\
\hline & Kasaba & $-.74008^{*}$ & .24919 & .026 \\
\hline & İlçe & .26392 & .14494 & .363 \\
\hline & Büyük Şehir & .32110 & .23493 & .649 \\
\hline \multirow{4}{*}{ Büyük Şehir } & Köy & -.45546 & .33865 & .663 \\
\hline & Kasaba & $-1.06118^{*}$ & .33240 & .013 \\
\hline & İlçe & -.05718 & .26344 & 1.000 \\
\hline & İl & -.32110 & .23493 & .649 \\
\hline
\end{tabular}

Tablo incelendiğinde hayatlarının büyük çoğunluğunu kasabada geçiren öğrencilerin DKAB dersine yönelik tutumları, hayatlarının büyük çoğunluğunu ilçede geçiren öğrencilerden anlamlı bir şekilde yüksek olduğu görülmektedir. Bunun nedeni, kasabada öğrenim gören öğrencilerin din eğitimini aldıkları kaynakların daha zengin, insanî ilişkilerin daha güçlü olması olabilir. Zengin (2013) araştırmasında öğrencilerin yerleşim yerlerine göre DKAB dersine yönelik tutumlarında anlamlı farklılıklar tespit edilmiştir. Araştırmaya göre köyde ikamet eden öğrencilerin DKAB dersine yönelik tutum düzeyleri diğer yerleşim yerlerinde ikamet edenlerden daha yüksektir. İl merkezlerinde DKAB dersine karşı olumlu tutum diğer yerleşim yerlerine göre daha azdır. Kaya'nın (2001) araştırmasında da köyde ikamet edenlerin tutum puanlan diğer yerleşim yerlerinde oturanlardan daha fazla çıkmıştır. Onun araştırma sonuçlarına göre ise en düşük tutum puanına kasaba-ilçede oturan öğrenciler sahip gözükmektedir. Bu durum bu araştırmalardaki bulgular ile bizim araştırmamızın bulguları arasında paralellik olduğu anlamına gelmektedir.

Tablo 29

DKAB Dersi Programının Yapısına Yönelik Tutumları Ile Hayatlarının Büyük Çoğunluğunu Geçirdikleri Yer Arasındaki İlişki

\begin{tabular}{lllllll}
\hline & & $\begin{array}{l}\text { Sum of } \\
\text { Squares }\end{array}$ & df & $\begin{array}{l}\text { Mean } \\
\text { Square }\end{array}$ & F & Sig. \\
\hline \multirow{2}{*}{$\begin{array}{l}\text { DKAB dersi } \\
\text { programinin } \\
\text { yapisina yönelik } \\
\text { tutum }\end{array}$} & $\begin{array}{l}\text { Between } \\
\text { Groups }\end{array}$ & 10.876 & 4 & 2.719 & 2.755 & .028 \\
\cline { 2 - 6 } & Within & 345.464 & 350 & .987 & \\
\cline { 2 - 6 } & Groups & 356.340 & 354 & & \\
\hline
\end{tabular}

Öğrencilerin hayatlarının büyük çoğunluğunu geçirdikleri yer ile DKAB dersi programının yapısına yönelik tutumları arasında anlamlı bir ilişki yoktur. $\mathrm{Bu}$ ilişkiyi gösteren tablo aşağıdaki gibidir: 
Tablo 30

DKAB Dersi Programının Yapısına Yönelik Tutumları İle Hayatlarının Büyük Çoğunluğunu Geçirdikleri Yer Arasındaki İlişki

\begin{tabular}{|c|c|c|c|c|c|}
\hline Bağımsız değişken & $\begin{array}{l}\text { (I) } \\
\text { Hayatlarının } \\
\text { büyük } \\
\text { çoğunluğunu } \\
\text { geçirdikleri } \\
\text { yer }\end{array}$ & $\begin{array}{l}(\mathrm{J}) \\
\text { Hayatlarının } \\
\text { büyük } \\
\text { çoğunluğunu } \\
\text { geçirdikleri } \\
\text { yer }\end{array}$ & $\begin{array}{l}\text { Mean } \\
\text { Difference (I-J) }\end{array}$ & Std. Error & Sig. \\
\hline \multirow{21}{*}{$\begin{array}{l}\text { DKAB dersi } \\
\text { programının } \\
\text { yapısına yönelik } \\
\text { tutum }\end{array}$} & \multirow{4}{*}{ Köy } & Kasaba & -.68943 & .36920 & .337 \\
\hline & & İlçe & .15937 & .30041 & .984 \\
\hline & & İl & -.00965 & .27261 & 1.000 \\
\hline & & Büyük Şehir & .38034 & .35856 & .826 \\
\hline & \multirow{4}{*}{ Kasaba } & Köy & .68943 & .36920 & .337 \\
\hline & & İlçe & $.84880^{*}$ & .29248 & .032 \\
\hline & & İl & .67978 & .26384 & .077 \\
\hline & & Büyük Şehir & $1.06976^{*}$ & .35194 & .021 \\
\hline & \multirow{5}{*}{ İlçe } & Köy & -.15937 & .30041 & .984 \\
\hline & & Kasaba & $-.84880^{*}$ & .29248 & .032 \\
\hline & & İl & -.16902 & .15347 & .806 \\
\hline & & Büyük Şehir & .22096 & .27893 & .933 \\
\hline & & Köy & .00965 & .27261 & 1.000 \\
\hline & \multirow{3}{*}{ İl } & Kasaba & -.67978 & .26384 & .077 \\
\hline & & İlçe & .16902 & .15347 & .806 \\
\hline & & Büyük Şehir & .38999 & .24874 & .519 \\
\hline & \multirow{5}{*}{$\begin{array}{l}\text { Büyük Şehir } \\
\text { Köy }\end{array}$} & Köy & -.38034 & .35856 & .826 \\
\hline & & Kasaba & $-1.06976^{*}$ & .35194 & .021 \\
\hline & & İlçe & -.22096 & .27893 & .933 \\
\hline & & İl & -.38999 & .24874 & .519 \\
\hline & & Kasaba & -.68943 & .36920 & .337 \\
\hline
\end{tabular}

Öğrencilerin hayatlarının büyük çoğunluğunu geçirdikleri yer ile DKAB dersi programının temel ilke ve hedeflerine yönelik tutumlarının ilişkilendirilmesi aşağıdaki gibidir: 
Tablo 31

DKAB Dersi Programının Temel Ilke Ve Hedeflerine Yönelik Tutumları İle Hayatlarının Büyük Çoğunluğunu Geçirdikleri Yer Arasındaki İlişki

\begin{tabular}{lllllll}
\hline & & $\begin{array}{l}\text { Sum of } \\
\text { Squares }\end{array}$ & df & $\begin{array}{l}\text { Mean } \\
\text { Square }\end{array}$ & F & Sig. \\
\hline \multirow{2}{*}{$\begin{array}{l}\text { DKAB dersi } \\
\text { programinin } \\
\text { temel ilke ve } \\
\text { hedeflerine }\end{array}$} & $\begin{array}{l}\text { Between } \\
\text { Groups }\end{array}$ & 8.355 & 4 & 2.089 & 2.446 & .046 \\
\cline { 2 - 6 } & Within & 298.897 & 350 & .854 & \\
\cline { 2 - 6 } & Groups & 307.252 & 354 & & \\
\hline
\end{tabular}

Öğrencilerin hayatlarının büyük çoğunluğunu geçirdikleri yer ile DKAB dersi programının temel ilke ve hedeflerine yönelik tutumları arasında anlamlı bir ilişki yoktur. Bu ilişkiyi gösteren tablo aşağıdaki gibidir:

Tablo 32

DKAB Dersi Programının Temel Ilke Ve Hedeflerine Yönelik Tutumlar Ile Hayatlarının Büyük Çoğunluğunu Geçirdikleri Yer Arasındaki İlişki

\begin{tabular}{|c|c|c|c|c|c|}
\hline Bağımsız değişken & $\begin{array}{l}\text { (I) } \\
\text { Hayatlarının } \\
\text { büyük } \\
\text { çoğunluğunu } \\
\text { geçirdikleri } \\
\text { yer }\end{array}$ & $\begin{array}{l}\text { (J) } \\
\text { Hayatlarının } \\
\text { büyük } \\
\text { çoğunluğunu } \\
\text { geçirdikleri } \\
\text { yer }\end{array}$ & $\begin{array}{l}\text { Mean } \\
\text { Difference (I-J) }\end{array}$ & Std. Error & Sig. \\
\hline \multirow{17}{*}{$\begin{array}{l}\text { DKAB dersi } \\
\text { programının temel } \\
\text { ilke ve hedeflerine } \\
\text { yönelik tutum }\end{array}$} & \multirow{4}{*}{ Köy } & Kasaba & -.58095 & .34341 & .440 \\
\hline & & İlçe & .11371 & .27943 & .994 \\
\hline & & İl & -.06564 & .25357 & .999 \\
\hline & & Büyük Şehir & .35042 & .33352 & .831 \\
\hline & \multirow{4}{*}{ Kasaba } & Köy & .58095 & .34341 & .440 \\
\hline & & İlçe & .69467 & .27205 & .082 \\
\hline & & İl & .51532 & .24542 & .222 \\
\hline & & Büyük Şehir & $.93137^{*}$ & .32736 & .038 \\
\hline & \multirow{5}{*}{ İlçe } & Köy & -.11371 & .27943 & .994 \\
\hline & & Kasaba & -.69467 & .27205 & .082 \\
\hline & & İl & -.17935 & .14275 & .718 \\
\hline & & Büyük Şehir & .23671 & .25945 & .892 \\
\hline & & Köy & .06564 & .25357 & .999 \\
\hline & \multirow{3}{*}{ İl } & Kasaba & -.51532 & .24542 & .222 \\
\hline & & İlçe & .17935 & .14275 & .718 \\
\hline & & Büyük Şehir & .41606 & .23137 & .376 \\
\hline & Büyük Şehir & Köy & -.35042 & .33352 & .831 \\
\hline
\end{tabular}




\begin{tabular}{llll} 
Kasaba & $-.93137^{*}$ & .32736 & .038 \\
\hline İlçe & -.23671 & .25945 & .892 \\
\hline İl & -.41606 & .23137 & .376 \\
\hline
\end{tabular}

Öğrencilerin hayatlarının büyük çoğunluğunu geçirdikleri yer ile DKAB dersi programının amacı, içerik ve uygulanmasına yönelik tutumlarının ilişkilendirilmesi aşağıdaki gibidir:

Tablo 33

DKAB Dersi Programının Amacı, İçerik Ve Uygulanmasına Yönelik Tutumları İle Hayatlarının Büyük Çoğunluğunu Geçirdikleri Yer Arasındaki İlişki

\begin{tabular}{|c|c|c|c|c|c|c|}
\hline & & $\begin{array}{l}\text { Sum of } \\
\text { Squares }\end{array}$ & $\mathrm{df}$ & $\begin{array}{l}\text { Mean } \\
\text { Square }\end{array}$ & $\mathrm{F}$ & Sig. \\
\hline \multirow{3}{*}{$\begin{array}{l}\text { DKAB dersi } \\
\text { programının amacı, } \\
\text { içerik ve } \\
\text { uygulanmasına } \\
\text { yönelik tutum }\end{array}$} & $\begin{array}{l}\text { Between } \\
\text { Groups }\end{array}$ & \multicolumn{2}{|l|}{8.355} & 2.089 & 2.446 & .046 \\
\hline & $\begin{array}{l}\text { Within } \\
\text { Groups }\end{array}$ & 298.897 & 50 & .854 & & \\
\hline & Toplam & 307.252 & 54 & & & \\
\hline
\end{tabular}

Öğrencilerin hayatlarının büyük çoğunluğunu geçirdikleri yer ile DKAB dersi programının amacı, içerik ve uygulanmasına yönelik tutumları arasında anlamlı bir ilişki yoktur. Bu ilişkiyi gösteren tablo aşağıdaki gibidir:

Tablo 34

DKAB Dersi Programının Amacı, İçerik Ve Uygulanmasına Yönelik Tutumları İle Hayatlarının Büyük Çoğunluğunu Geçirdikleri Yer Arasındaki İlişki

\begin{tabular}{|c|c|c|c|c|c|}
\hline Bağımsız değişken & $\begin{array}{l}\text { (I) } \\
\text { Hayatlarının } \\
\text { büyük } \\
\text { çoğunluğunu } \\
\text { geçirdikleri } \\
\text { yer }\end{array}$ & $\begin{array}{l}\text { (J) } \\
\text { Hayatlarının } \\
\text { büyük } \\
\text { çoğunluğunu } \\
\text { geçirdikleri } \\
\text { yer }\end{array}$ & $\begin{array}{l}\text { Mean } \\
\text { Difference (I-J) }\end{array}$ & Std. Error & Sig. \\
\hline \multirow{8}{*}{$\begin{array}{l}\text { DKAB dersi } \\
\text { programının amacı, } \\
\text { içerik ve } \\
\text { uygulanmasına } \\
\text { yönelik tutum }\end{array}$} & \multirow{4}{*}{ Köy } & Kasaba & -.58095 & .34341 & .440 \\
\hline & & İlçe & .11371 & .27943 & .994 \\
\hline & & İl & -.06564 & .25357 & .999 \\
\hline & & Büyük Şehir & .35042 & .33352 & .831 \\
\hline & \multirow{4}{*}{ Kasaba } & Köy & .58095 & .34341 & .440 \\
\hline & & İlçe & .69467 & .27205 & .082 \\
\hline & & İl & .51532 & .24542 & .222 \\
\hline & & Büyük Şehir & $.93137^{*}$ & .32736 & .038 \\
\hline
\end{tabular}




\begin{tabular}{lllll} 
& Köy & -.11371 & .27943 & .994 \\
\cline { 2 - 5 } İlçe & Kasaba & -.69467 & .27205 & .082 \\
\cline { 2 - 5 } & İl & -.17935 & .14275 & .718 \\
\cline { 2 - 5 } & Büyük Şehir & .23671 & .25945 & .892 \\
\cline { 2 - 5 } & Köy & .06564 & .25357 & .999 \\
\hline \multirow{3}{*}{ İl } & Kasaba & -.51532 & .24542 & .222 \\
\cline { 2 - 5 } & İlçe & .17935 & .14275 & .718 \\
\cline { 2 - 5 } & Büyük Şehir & .41606 & .23137 & .376 \\
\hline \multirow{3}{*}{ Büyük Şehir } & Köy & -.35042 & .33352 & .831 \\
\cline { 2 - 5 } & Kasaba & $-.93137^{*}$ & .32736 & .038 \\
\cline { 2 - 5 } & İlçe & -.23671 & .25945 & .892 \\
\cline { 2 - 5 } & İl & -.41606 & .23137 & .376
\end{tabular}

Öğrencilerin din eğitimini aldıkları kaynaklar ile tutum puanları arasındaki ilişki.

Tablo 35

Öğrencilerin Din Eğitimini Aldıkları Kaynaklar

\begin{tabular}{llc}
\hline \multirow{2}{*}{ Din Eğitimi Alınan Yer } & \multicolumn{2}{c}{ Evet } \\
\cline { 2 - 3 } & N & $\%$ \\
\hline Aileden & 286 & 80.6 \\
\hline Kur'an Kurslarında & 165 & 46.5 \\
\hline Orta öğretimde Din Kültürü ve Ahlak Bilgisi derslerinde & 155 & 43.7 \\
\hline Kendi kendime & 80 & 22.5 \\
\hline Dini bilgim yok & 10 & 2.8 \\
\hline Diğer & 13 & 3.7 \\
\hline
\end{tabular}

${ }^{1}$ Birden fazla cevap vardır. 
Din eğitimini aileden alan öğrenciler ile tutum puanları arasındaki ilişki. Din eğitimini aileden alan öğrenciler ile tutumlar arasındaki ilişkileri gösteren tablolar aşağıdaki gibidir:

Tablo 36

DKAB Dersine Yönelik Tutumları İle Din Eğitimini Aileden Alan Öğrenciler Arasındaki Ilişki

Levene's Test for Equality of Variances

\begin{tabular}{|c|c|c|c|c|c|c|}
\hline & & & & & & \\
\hline & & $\mathrm{F}$ & Sig & $\mathrm{t}$ & df & Sig. (2-tailed) \\
\hline \multirow{2}{*}{$\begin{array}{l}\text { DKAB } \\
\text { dersine } \\
\text { yönelik } \\
\text { tutum }\end{array}$} & $\begin{array}{l}\text { Equal variances } \\
\text { assumed }\end{array}$ & .014 & .904 & -.128 & 353 & .898 \\
\hline & $\begin{array}{l}\text { Equal variances } \\
\text { not assumed }\end{array}$ & & & -.129 & 103.962 & .898 \\
\hline
\end{tabular}

Din eğitimini aileden alan öğrenciler ile $\mathrm{DKAB}$ dersine yönelik tutumları arasında anlamlı bir ilişki yoktur.

Tablo 37

DKAB Dersi Programının Yapısına Yönelik Tutumları İle Din Eğitimini Aileden Alan Öğrenciler Arasındaki İlişki

\begin{tabular}{lllllll}
\hline & \multicolumn{5}{c}{ Levene's Test for Equality of Variances } \\
\cline { 2 - 7 } & & $\mathrm{F}$ & $\mathrm{Sig}$. & $\mathrm{t}$ & $\mathrm{df}$ & Sig. (2-tailed) \\
\hline $\begin{array}{l}\text { DKAB dersi } \\
\text { programının } \\
\begin{array}{l}\text { yapisina yönelik } \\
\text { tutum }\end{array}\end{array}$ & $\begin{array}{l}\text { Equal variances } \\
\text { assumed }\end{array}$ & .393 & .531 & .097 & 353 & .923 \\
\cline { 2 - 6 } & $\begin{array}{l}\text { Equal variances } \\
\text { not assumed }\end{array}$ & & & .100 & 106.521 & .921 \\
\hline
\end{tabular}

Din eğitimini aileden alan öğrenciler ile $\mathrm{DKAB}$ dersi programının yapısına yönelik tutumları arasında anlamlı bir ilişki yoktur.

Tablo 38

DKAB Dersi Programının Temel Illke ve Hedeflerine Yönelik Tutumlar İle Din Ĕ̈itimini Aileden Alan Öğrenciler Arasındaki İlişki

\begin{tabular}{|c|c|c|c|c|c|c|}
\hline & & \multicolumn{5}{|c|}{ Levene's Test for Equality of Variances } \\
\hline & & $\mathrm{F}$ & Sig. & $\mathrm{t}$ & df & $\begin{array}{l}\text { Sig. (2- } \\
\text { tailed) }\end{array}$ \\
\hline \multirow{2}{*}{$\begin{array}{l}\text { DKAB dersi } \\
\text { programının } \\
\text { temel ilke ve } \\
\text { hedeflerine } \\
\text { yönelik tutum }\end{array}$} & $\begin{array}{l}\text { Equal variances } \\
\text { assumed }\end{array}$ & .013 & .911 & -.050 & 353 & .960 \\
\hline & $\begin{array}{l}\text { Equal variances } \\
\text { not assumed }\end{array}$ & & & -.050 & 101.836 & .961 \\
\hline
\end{tabular}


Din eğitimini aileden alan öğrenciler ile DKAB dersi programının temel ilke ve hedeflerine yönelik tutumları arasında anlamlı bir ilişki yoktur.

Tablo 39

DKAB Dersi Programının Temel Ilke ve Hedeflerine Yönelik Tutumlar Ile Din Ĕ̈itimini Aileden Alan Öğrenciler Arasındaki İlişki

\begin{tabular}{|c|c|c|c|c|c|c|}
\hline & & \multicolumn{5}{|c|}{ Levene's Test for Equality of Variances } \\
\hline & & $\mathrm{F}$ & Sig. & $\mathrm{t}$ & df & $\begin{array}{l}\text { Sig. (2- } \\
\text { tailed) }\end{array}$ \\
\hline \multirow{2}{*}{$\begin{array}{l}\text { DKAB dersi } \\
\text { programının } \\
\text { amacı, içerik ve } \\
\text { uygulanmasına } \\
\text { yönelik tutum }\end{array}$} & $\begin{array}{l}\text { Equal variances } \\
\text { assumed }\end{array}$ & .013 & .911 & -.050 & 353 & .960 \\
\hline & $\begin{array}{l}\text { Equal variances } \\
\text { not assumed }\end{array}$ & & & -.050 & 101.836 & .961 \\
\hline
\end{tabular}

Din eğitimini aileden alan öğrenciler ile $\mathrm{DKAB}$ dersi programının amacı, içerik ve uygulanmasına yönelik tutumları arasında anlamlı bir ilişki yoktur.

Din eğitimini kendi kendine alan öğrenciler ile tutum puanları arasındaki ilişki. Din eğitimini kendi kendine aldıklarını ifade eden öğrenciler ile tutumlar arasındaki ilişkileri gösteren tablolar aşağıdaki gibidir:

Tablo 40

DKAB Dersine Yönelik Tutumları İle Din Eğitimini Kendi Kendine Alan Öğrenciler Arasındaki İlişki

\begin{tabular}{lllllll}
\hline \multicolumn{5}{c}{} & \multicolumn{5}{c}{ Levene's Test for Equality of Variances } \\
\cline { 2 - 7 } & & $\mathrm{F}$ & $\mathrm{Sig}$. & $\mathrm{t}$ & $\mathrm{df}$ & Sig. (2-tailed) \\
\hline $\begin{array}{l}\text { DKAB } \\
\text { dersine } \\
\text { yönelik } \\
\text { tutum }\end{array}$ & $\begin{array}{l}\text { Equal variances } \\
\text { assumed }\end{array}$ & 2.863 & .092 & .761 & 353 & .447 \\
\cline { 2 - 6 } & $\begin{array}{l}\text { Equal variances } \\
\text { not assumed }\end{array}$ & & & .705 & 115.939 & .482 \\
\hline
\end{tabular}


Din eğitimini kendi kendine aldıklarını ifade eden öğrenciler ile DKAB dersine yönelik tutumları arasında anlamlı bir ilişki yoktur.

Tablo 41

DKAB Dersi Programının Yapısına Yönelik Tutumları İle Din Eğitimini Kendi Kendine Alan Öğrenciler Arasındaki İlişki

Levene's Test for Equality of Variances

\begin{tabular}{|c|c|c|c|c|c|c|}
\hline & & & & & \\
\hline & & $\mathrm{F}$ & Sig. & $\mathrm{t}$ & $\mathrm{df}$ & Sig. (2-tailed) \\
\hline \multirow{2}{*}{$\begin{array}{l}\text { DKAB dersi } \\
\text { programının } \\
\text { yapısına yönelik } \\
\text { tutum }\end{array}$} & $\begin{array}{l}\text { Equal variances } \\
\text { assumed }\end{array}$ & 3.219 & .074 & .782 & 353 & .435 \\
\hline & $\begin{array}{l}\text { Equal variances } \\
\text { not assumed }\end{array}$ & & & .725 & 116.226 & .470 \\
\hline
\end{tabular}

Din eğitimini kendi kendine aldıklarını ifade eden öğrenciler ile DKAB dersi programının yapısına yönelik tutumları arasında anlamlı bir ilişki yoktur.

Tablo 42

DKAB Dersi Programının Temel İlke Ve Hedeflerine Yönelik Tutumları İle Din Ĕ̈itimini Kendi Kendine Alan Öğrenciler Arasındaki İlişki

\begin{tabular}{lllllll}
\hline & \multicolumn{5}{c}{ Levene's Test for Equality of Variances } \\
\cline { 3 - 7 } & & $\mathrm{F}$ & Sig. & $\mathrm{t}$ & $\mathrm{df}$ & $\begin{array}{l}\text { Sig. (2- } \\
\text { tailed) }\end{array}$ \\
\hline $\begin{array}{l}\text { DKAB dersi } \\
\text { programının }\end{array}$ & $\begin{array}{l}\text { Equal variances } \\
\text { assumed }\end{array}$ & 2.205 & .138 & -.486 & 353 & .627 \\
\cline { 2 - 6 } $\begin{array}{l}\text { temel ilke ve } \\
\text { hedeflerine } \\
\text { yönelik tutum }\end{array}$ & $\begin{array}{l}\text { Equal variances } \\
\text { not assumed }\end{array}$ & & & -.456 & 117.618 & .649 \\
\hline
\end{tabular}

Din eğitimini kendi kendine aldıklarını ifade eden öğrenciler ile DKAB dersi programının temel ilke ve hedeflerine yönelik tutumları arasında anlamlı bir ilişki yoktur.

Tablo 43

DKAB Dersi Programının Amacı, İçerik ve Uygulanmasına Yönelik Tutumları İle Din Ĕ̆itimini Kendi Kendine Alan Öğrenciler Arasındaki İlişki

\begin{tabular}{|c|c|c|c|c|c|c|}
\hline & & \multicolumn{5}{|c|}{$\begin{array}{l}\text { Levene's Test for Equality of } \\
\text { Variances }\end{array}$} \\
\hline & & $\mathrm{F}$ & Sig. & $\mathrm{t}$ & df & $\begin{array}{l}\text { Sig. (2- } \\
\text { tailed) }\end{array}$ \\
\hline \multirow{2}{*}{$\begin{array}{l}\text { DKAB dersi programının amacı, } \\
\text { içerik ve uygulanmasına yönelik } \\
\text { tutum }\end{array}$} & $\begin{array}{l}\text { Equal variances } \\
\text { assumed }\end{array}$ & 2.205 & .138 & -.486 & 353 & .627 \\
\hline & $\begin{array}{l}\text { Equal variances } \\
\text { not assumed }\end{array}$ & & & -.456 & 117.618 & .649 \\
\hline
\end{tabular}


Din eğitimini kendi kendine aldıklarını ifade eden öğrenciler ile DKAB dersi programının amacı, içerik ve uygulanmasına yönelik tutumları arasında anlamlı bir ilişki yoktur.

Din eğitimini kuran kurslarından alan öğrenciler ile tutum puanları arasındaki ilişki. Din eğitimini Kuran kursundan alan öğrenciler ile tutumlar arasındaki ilişkileri gösteren tablolar aşağıdaki gibidir:

Tablo 44

DKAB Dersine Yönelik Tutumları İle Din Eğitimini Kur'an Kursundan Alan Öğrenciler Arasındaki İlişki

\begin{tabular}{lllllll}
\hline & \multicolumn{5}{c}{ Levene's Test for Equality of Variances } \\
\cline { 3 - 6 } & & $\mathrm{F}$ & $\mathrm{Sig}$. & $\mathrm{t}$ & $\mathrm{df}$ & Sig. (2-tailed) \\
\hline $\begin{array}{l}\text { DKAB } \\
\text { dersine } \\
\begin{array}{l}\text { yönelik } \\
\text { tutum }\end{array}\end{array}$ & $\begin{array}{l}\text { Equal variances } \\
\text { assumed }\end{array}$ & .643 & .423 & -5.123 & 353 & .000 \\
\cline { 2 - 6 } & $\begin{array}{l}\text { Equal variances } \\
\text { not assumed }\end{array}$ & & & -5.149 & 351.162 & .000 \\
\hline
\end{tabular}

Din eğitimini Kur'an kursundan alan öğrenciler ile DKAB dersine yönelik tutumları arasında anlamlı bir ilişki vardır. Din eğitimini Kur'an kursundan alan öğrencilerin DKAB dersine yönelik tutumları, diğer öğrencilerin DKAB dersine yönelik tutumlarından anlamlı bir şekilde daha yüksektir. Zengin'in (2013) araştırmasında DKAB dersi almadan önce ailede veya camide din eğitimi alma durumunun öğrenci tutumlarını anlamlı düzeyde etkilediği görülmektedir. Buna göre ailede ve camide daha önce eğitim almış öğrencilerin DKAB dersine yönelik tutumları, almayanlara göre daha yüksektir.

Tablo 45

DKAB Dersi Programının Yapısına Yönelik Tutumları İle Din Eğitimini Kur’an Kursundan Alan Öğrenciler Arasındaki İlişki

\begin{tabular}{lllllll}
\hline & \multicolumn{5}{c}{ Levene's Test for Equality of Variances } \\
\cline { 2 - 7 } & & $\mathrm{F}$ & $\mathrm{Sig}$. & $\mathrm{t}$ & $\mathrm{df}$ & Sig. (2-tailed) \\
\hline $\begin{array}{l}\text { DKAB dersi } \\
\text { programinin } \\
\text { yapisina yönelik } \\
\text { tutum }\end{array}$ & $\begin{array}{l}\text { Equal variances } \\
\text { assumed }\end{array}$ & .266 & .606 & -4.923 & 353 & .000 \\
\cline { 2 - 6 } & $\begin{array}{l}\text { Equal variances } \\
\text { not assumed }\end{array}$ & & & -4.908 & 341.230 & .000 \\
\hline
\end{tabular}

Din eğitimini Kur'an kursundan alan öğrenciler ile DKAB dersi programının yapısına yönelik tutumları arasında anlamlı bir ilişki vardır. Din eğitimini Kur'an kursundan alan öğrencilerin DKAB dersi programının yapısına yönelik tutumları, diğer öğrencilerin DKAB dersi programının yapısına yönelik tutumlarından anlamlı bir şekilde daha yüksektir. 
Tablo 46

DKAB Dersi Programının Temel İlke ve Hedeflerine Yönelik Tutumlarl İe Din Ĕ̈itimini Kur'an Kursundan Alan Öğrenciler Arasındaki İlişki

\begin{tabular}{|c|c|c|c|c|c|c|}
\hline & & \multicolumn{5}{|c|}{ Levene's Test for Equality of Variances } \\
\hline & & $\mathrm{F}$ & Sig. & $\mathrm{t}$ & $\mathrm{df}$ & $\begin{array}{l}\text { Sig. (2- } \\
\text { tailed) }\end{array}$ \\
\hline \multirow{2}{*}{$\begin{array}{l}\text { DKAB dersi } \\
\text { programının } \\
\text { temel ilke ve } \\
\text { hedeflerine } \\
\text { yönelik tutum }\end{array}$} & $\begin{array}{l}\text { Equal variances } \\
\text { assumed }\end{array}$ & .006 & .938 & -5.185 & 353 & .000 \\
\hline & $\begin{array}{l}\text { Equal variances } \\
\text { not assumed }\end{array}$ & & & -5.183 & 345.740 & .000 \\
\hline
\end{tabular}

Din eğitimini Kur'an kursundan alan öğrenciler ile DKAB dersi programının temel ilke ve hedeflerine yönelik tutumları arasında anlamlı bir ilişki vardır. Din eğitimini Kur'an kursundan alan öğrencilerin DKAB dersi programının temel ilke ve hedeflerine yönelik tutumları, diğer öğrencilerin DKAB dersi programının temel ilke ve hedeflerine yönelik tutumlarından anlamlı bir şekilde daha yüksektir.

Tablo 47

DKAB Dersi Programının Amacı, İçerik ve Uygulanmasına Yönelik Tutumları İle Din Eğitimini Kur'an Kursundan Alan Ö̆grenciler Arasındaki İlişki

\begin{tabular}{|c|c|c|c|c|c|c|}
\hline & & \multicolumn{5}{|c|}{ Levene's Test for Equality of Variances } \\
\hline & & $\mathrm{F}$ & Sig. & $\mathrm{t}$ & df & $\begin{array}{l}\text { Sig. (2- } \\
\text { tailed) }\end{array}$ \\
\hline \multirow{2}{*}{$\begin{array}{l}\text { DKAB dersi } \\
\text { programının } \\
\text { amacı, içerik ve } \\
\text { uygulanmasına } \\
\text { yönelik tutum }\end{array}$} & $\begin{array}{l}\text { Equal variances } \\
\text { assumed }\end{array}$ & .006 & .938 & -5.185 & 353 & .000 \\
\hline & $\begin{array}{l}\text { Equal variances } \\
\text { not assumed }\end{array}$ & & & -5.183 & 345.740 & .000 \\
\hline
\end{tabular}

Din eğitimini Kur'an kursundan alan öğrenciler ile DKAB dersi programının amacı, içerik ve uygulanmasına yönelik tutumları arasında anlamlı bir ilişki vardır. Din eğitimini Kur'an kursundan alan öğrencilerin DKAB dersi programının amacı, içerik ve uygulanmasına yönelik tutumları, diğer öğrencilerin DKAB dersi programının amacı, içerik ve uygulanmasına yönelik tutumlarından anlamlı bir şekilde daha yüksektir. 
Din eğitimini ortaöğretim DKAB dersinden alan öğrenciler ile tutum puanları arasındaki ilişki. Din eğitimini ortaöğretim DKAB dersinden alan öğrenciler ile tutumlar arasındaki ilişkileri gösteren tablolar aşağıdaki gibidir:

Tablo 48

DKAB Dersine Yönelik Tutumları İle Din Eğitimini Ortaöğretim DKAB Dersinden Alan Öğrenciler Arasındaki İlişki

\begin{tabular}{lllllll}
\hline \multicolumn{5}{c}{} & \multicolumn{5}{c}{ Levene's Test for Equality of Variances } \\
\cline { 3 - 6 } & & $\mathrm{F}$ & $\mathrm{Sig}$. & $\mathrm{t}$ & $\mathrm{df}$ & Sig. (2-tailed) \\
\hline $\begin{array}{l}\text { DKAB } \\
\text { dersine } \\
\text { yönelik } \\
\text { tutum }\end{array}$ & $\begin{array}{l}\text { Equal variances } \\
\text { assumed }\end{array}$ & .815 & .367 & -3.795 & 353 & .000 \\
\cline { 2 - 6 } & $\begin{array}{l}\text { Equal variances } \\
\text { not assumed }\end{array}$ & & -3.811 & 336.206 & .000 \\
\hline
\end{tabular}

Din eğitimini ortaöğretim DKAB dersinden alan öğrenciler ile DKAB dersine yönelik tutumları arasında anlamlı bir ilişki vardır. Din eğitimini ortaöğretim DKAB dersinden alan öğrencilerin $\mathrm{DKAB}$ dersine yönelik tutumları, diğer öğrencilerin $\mathrm{DKAB}$ dersine yönelik tutumlarından anlamlı bir şekilde daha yüksektir. Zengin'in (2013) araştırmasında DKAB dersinde yeterli bir din ve ahlak eğitimi alabilme durumuna göre öğrencilerin DKAB dersine karşı tutumlarında anlamlı bir farklılık tespit edilmiştir. Buna göre yeterli bir din ve ahlak eğitimi alabildiğini düşünen öğrencilerin derse yönelik tutumları daha yüksek çıkarken, alamadığını belirten öğrencilerin tutumları daha düşük çıkmaktadır. Kaya'nın (2001) araştırmasında da öğrencilerin DKAB dersinde yeterli din ve ahlak eğitimi almaları ile derse karşı tutumları arasında anlamlı farklılık tespit edilmiştir.

Tablo 49

DKAB Dersi Programının Yapısına Yönelik Tutumları İle Din Eğitimini Ortaöğretim DKAB Dersinden Alan Öğrenciler Arasındaki İlişki

\begin{tabular}{lllllll}
\hline & \multicolumn{5}{c}{ Levene's Test for Equality of Variances } \\
\cline { 2 - 7 } & & $\mathrm{F}$ & $\mathrm{Sig}$. & $\mathrm{t}$ & $\mathrm{df}$ & Sig. (2-tailed) \\
\hline $\begin{array}{l}\text { DKAB dersi } \\
\text { programının } \\
\begin{array}{l}\text { yapisına yönelik } \\
\text { tutum }\end{array}\end{array}$ & $\begin{array}{l}\text { Equal variances } \\
\text { assumed }\end{array}$ & .041 & .839 & -4.161 & 353 & .000 \\
\cline { 2 - 6 } & $\begin{array}{l}\text { Equal variances } \\
\text { not assumed }\end{array}$ & & & -4.150 & 327.710 & .000 \\
\hline
\end{tabular}

Din eğitimini ortaöğretim $\mathrm{DKAB}$ dersinden alan öğrenciler ile DKAB dersi programının yapısına yönelik tutumları arasında anlamlı bir ilişki vardır. Din eğitimini ortaöğretim DKAB dersinden alan öğrencilerin DKAB dersi programının yapısına yönelik tutumları, diğer öğrencilerin $\mathrm{DKAB}$ dersi programının yapısına yönelik tutumlarından anlamlı bir şekilde daha yüksektir. 
Tablo 50

DKAB Dersi Programının Temel Ilke Ve Hedeflerine Yönelik Tutumları Ile Din Ĕ̈itimini Ortaöğretim DKAB Dersinden Alan Öğrenciler Arasındaki İlişki

\begin{tabular}{|c|c|c|c|c|c|c|}
\hline & & \multicolumn{5}{|c|}{ Levene's Test for Equality of Variances } \\
\hline & & $\mathrm{F}$ & Sig. & $\mathrm{t}$ & $\mathrm{df}$ & $\begin{array}{l}\text { Sig. (2- } \\
\text { tailed) }\end{array}$ \\
\hline \multirow{2}{*}{$\begin{array}{l}\text { DKAB dersi } \\
\text { programının } \\
\text { temel ilke ve } \\
\text { hedeflerine } \\
\text { yönelik tutum }\end{array}$} & $\begin{array}{l}\text { Equal variances } \\
\text { assumed }\end{array}$ & .164 & .686 & -3.995 & 353 & .000 \\
\hline & $\begin{array}{l}\text { Equal variances } \\
\text { not assumed }\end{array}$ & & & -3.993 & 330.598 & .000 \\
\hline
\end{tabular}

Din eğitimini ortaöğretim DKAB dersinden alan öğrenciler ile DKAB dersi programının temel ilke ve hedeflerine yönelik tutumları arasında anlamlı bir ilişki vardır. Din eğitimini ortaöğretim $\mathrm{DKAB}$ dersinden alan öğrencilerin $\mathrm{DKAB}$ dersi programının temel ilke ve hedeflerine yönelik tutumları, diğer öğrencilerin DKAB dersi programının temel ilke ve hedeflerine yönelik tutumlarından anlamlı bir şekilde daha yüksektir.

\section{Tablo 51}

DKAB Dersi Programının Amacı, İçerik Ve Uygulanmasına Yönelik Tutumları İle Din Ĕ̈itimini Ortaöğretim DKAB Dersinden Alan Öğrenciler Arasındaki İlişki

\begin{tabular}{|c|c|c|c|c|c|c|}
\hline & & \multicolumn{5}{|c|}{ Levene's Test for Equality of Variances } \\
\hline & & $\mathrm{F}$ & Sig. & $\mathrm{t}$ & df & $\begin{array}{l}\text { Sig. (2- } \\
\text { tailed) }\end{array}$ \\
\hline \multirow{2}{*}{$\begin{array}{l}\text { DKAB dersi } \\
\text { programının } \\
\text { amacı, içerik ve } \\
\text { uygulanmasına } \\
\text { yönelik tutum }\end{array}$} & $\begin{array}{l}\text { Equal variances } \\
\text { assumed }\end{array}$ & .164 & .686 & -3.995 & 353 & .000 \\
\hline & $\begin{array}{l}\text { Equal variances } \\
\text { not assumed }\end{array}$ & & & -3.993 & 330.598 & .000 \\
\hline
\end{tabular}

Din eğitimini ortaöğretim $\mathrm{DKAB}$ dersinden alan öğrenciler ile $\mathrm{DKAB}$ dersi programının amacı, içerik ve uygulanmasına yönelik tutumları arasında anlamlı bir ilişki vardır. Din eğitimini ortaöğretim $\mathrm{DKAB}$ dersinden alan öğrencilerin $\mathrm{DKAB}$ dersi programının amacı, içerik ve uygulanmasına yönelik tutumları, diğer öğrencilerin DKAB dersi programının amacı, içerik ve uygulanmasına yönelik tutumlarından anlamlı bir şekilde daha yüksektir. 
Dini bilgim yok diyen öğrenciler ile tutum puanları arasındaki ilişki. Dini bilgim yok diyen öğrenciler ile tutumlar arasındaki ilişkileri gösteren tablolar aşağıdaki gibidir:

Tablo 52

DKAB Dersine Yönelik Tutumları İle Dini Bilgim Yok Diyen Öğrenciler Arasındaki Illişki

\begin{tabular}{lllllll}
\hline \multicolumn{5}{c}{} & \multicolumn{5}{c}{ Levene's Test for Equality of Variances } \\
\cline { 3 - 6 } & $\mathrm{F}$ & Sig. & $\mathrm{t}$ & $\mathrm{df}$ & Sig. (2-tailed) \\
\hline $\begin{array}{l}\text { DKAB } \\
\text { dersine } \\
\text { yönelik } \\
\text { tutum }\end{array}$ & $\begin{array}{l}\text { Equal variances } \\
\text { assumed }\end{array}$ & .715 & .398 & 2.522 & 353 & .012 \\
\cline { 2 - 6 } & $\begin{array}{l}\text { Equal variances } \\
\text { not assumed }\end{array}$ & & 1.881 & 9.282 & .092 \\
\hline
\end{tabular}

Dini bilgim yok diyen öğrenciler ile DKAB dersine yönelik tutumları arasında anlamlıya yakın bir ilişki vardır. Dini bilgim yok diyen öğrencilerin DKAB dersine yönelik tutumları, diğer öğrencilerin $\mathrm{DKAB}$ dersine yönelik tutumlarından anlamlıya yakın bir şekilde daha düşüktür.

\section{Tablo 53}

DKAB Dersi Programının Yapısına Yönelik Tutumları İle Dini Bilgim Yok Diyen Öğrenciler Arasındaki İlişki

\begin{tabular}{lllllll}
\hline & \multicolumn{5}{c}{ Levene's Test for Equality of Variances } \\
\cline { 3 - 7 } & & $\mathrm{F}$ & $\mathrm{Sig}$. & $\mathrm{t}$ & $\mathrm{df}$ & Sig. (2-tailed) \\
\hline $\begin{array}{l}\text { DKAB dersi } \\
\text { programının } \\
\begin{array}{l}\text { yapisina yönelik } \\
\text { tutum }\end{array}\end{array}$ & $\begin{array}{l}\text { Equal variances } \\
\text { assumed }\end{array}$ & .350 & .554 & 1.564 & 353 & .119 \\
\cline { 2 - 6 } & $\begin{array}{l}\text { Equal variances } \\
\text { not assumed }\end{array}$ & & & 1.234 & 9.319 & .247 \\
\hline
\end{tabular}


Dini bilgim yok diyen öğrenciler ile DKAB dersi programının yapısına yönelik tutumları arasında anlamlı bir ilişki yoktur.

Tablo 54

DKAB Dersi Programının Temel İlke Ve Hedeflerine Yönelik Tutumları İle Dini Bilgim Yok Diyen Öğrenciler Arasındaki İlişki

Levene's Test for Equality of Variances

\begin{tabular}{|c|c|c|c|c|c|c|}
\hline & & \\
\hline & & $\mathrm{F}$ & Sig. & $\mathrm{t}$ & $\mathrm{df}$ & $\begin{array}{l}\text { Sig. (2- } \\
\text { tailed) }\end{array}$ \\
\hline \multirow{2}{*}{$\begin{array}{l}\text { DKAB dersi } \\
\text { programının } \\
\text { temel ilke ve } \\
\text { hedeflerine } \\
\text { yönelik tutum }\end{array}$} & $\begin{array}{l}\text { Equal variances } \\
\text { assumed }\end{array}$ & .159 & .691 & 1.745 & 353 & .082 \\
\hline & $\begin{array}{l}\text { Equal variances } \\
\text { not assumed }\end{array}$ & & & 1.336 & 9.299 & .213 \\
\hline
\end{tabular}

Dini bilgim yok diyen öğrenciler ile DKAB dersi programının temel ilke ve hedeflerine yönelik tutumları arasında anlamlı bir ilişki yoktur.

Tablo 55

DKAB Dersi Programının Amacı, İçerik Ve Uygulanmasına Yönelik Tutumları İle Dini Bilgim Yok Diyen Öğrenciler Arasındaki İlişki

\begin{tabular}{|c|c|c|c|c|c|c|}
\hline & & \multicolumn{5}{|c|}{ Levene's Test for Equality of Variances } \\
\hline & & $\mathrm{F}$ & Sig. & $\mathrm{t}$ & df & $\begin{array}{l}\text { Sig. (2- } \\
\text { tailed) }\end{array}$ \\
\hline \multirow{2}{*}{$\begin{array}{l}\text { DKAB dersi } \\
\text { programının } \\
\text { amacı, içerik ve } \\
\text { uygulanmasına } \\
\text { yönelik tutum }\end{array}$} & $\begin{array}{l}\text { Equal variances } \\
\text { assumed }\end{array}$ & .159 & .691 & 1.745 & 353 & .082 \\
\hline & $\begin{array}{l}\text { Equal variances } \\
\text { not assumed }\end{array}$ & & & 1.336 & 9.299 & .213 \\
\hline
\end{tabular}

Dini bilgim yok diyen öğrenciler ile DKAB dersi programının amacı, içerik ve uygulanmasına yönelik tutumları arasında anlamlı bir ilişki yoktur.

Tablolar incelendiğinde, dini bilgim yok diyen öğrencilerin sayısı çok düşüktür. Bu durum sağlıklı bir analiz yapılabilmesini engellemektedir. Yani karşılaştırma yapılan iki grubun katılımcıları arasında çok büyük fark vardır. 
Din eğitimini diğer kaynaklardan alan öğrenciler ile tutum puanları

arasındaki ilişki. Din eğitimini diğer kaynaklardan alan öğrenciler ile tutumlar arasındaki ilişkileri gösteren tablolar aşağıdaki gibidir:

Tablo 56

DKAB Dersine Yönelik Tutumları İle Din Eğitimini Diğer Kaynaklardan Alan Ö̆̆renciler Arasındaki İlişki

\begin{tabular}{lllllll}
\hline \multicolumn{5}{c}{} & \multicolumn{5}{c}{ Levene's Test for Equality of Variances } \\
\cline { 3 - 7 } & & $\mathrm{F}$ & $\mathrm{Sig}$. & $\mathrm{t}$ & $\mathrm{df}$ & Sig. (2-tailed) \\
\hline $\begin{array}{l}\text { DKAB } \\
\text { dersine }\end{array}$ & $\begin{array}{l}\text { Equal variances } \\
\text { assumed }\end{array}$ & .157 & .692 & -1.565 & 353 & .119 \\
\cline { 2 - 6 } $\begin{array}{l}\text { yönelik } \\
\text { tutum }\end{array}$ & $\begin{array}{l}\text { Equal variances } \\
\text { not assumed }\end{array}$ & & & -1.478 & 12.820 & .164 \\
\hline
\end{tabular}

Din eğitimini diğer kaynaklardan alan öğrenciler ile DKAB dersine yönelik tutumları arasında anlamlı bir ilişki yoktur.

Tablo 57

DKAB Dersi Programının Yapısına Yönelik Tutumları İle Din Eğitimini Diğer Kaynaklardan Alan Öğrenciler Arasındaki İlişki

\begin{tabular}{lllllll}
\hline & \multicolumn{5}{c}{ Levene's Test for Equality of Variances } \\
\cline { 3 - 7 } & & $\mathrm{F}$ & $\mathrm{Sig}$. & $\mathrm{t}$ & $\mathrm{df}$ & Sig. (2-tailed) \\
\hline $\begin{array}{l}\text { DKAB dersi } \\
\text { programının } \\
\text { yapisına yönelik } \\
\text { tutum }\end{array}$ & $\begin{array}{l}\text { Equal variances } \\
\text { assumed }\end{array}$ & 1.702 & .193 & -.114 & 353 & .909 \\
\cline { 2 - 6 } & $\begin{array}{l}\text { Equal variances } \\
\text { not assumed }\end{array}$ & & & -.097 & 12.648 & .924
\end{tabular}

Din eğitimini diğer kaynaklardan alan öğrenciler ile DKAB dersi programının yapısına yönelik tutumları arasında anlamlı bir ilişki yoktur.

Tablo 58

DKAB Dersi Programının Temel İlke Ve Hedeflerine Yönelik Tutumları Ile Din Ĕ̆itimini Diğer Kaynaklardan Alan Öğrenciler Arasındaki İlişki

\begin{tabular}{|c|c|c|c|c|c|c|}
\hline & & \multicolumn{5}{|c|}{ Levene's Test for Equality of Variances } \\
\hline & & $\mathrm{F}$ & Sig. & $\mathrm{t}$ & df & $\begin{array}{l}\text { Sig. (2- } \\
\text { tailed) }\end{array}$ \\
\hline \multirow{2}{*}{$\begin{array}{l}\text { DKAB dersi } \\
\text { programının } \\
\text { temel ilke ve } \\
\text { hedeflerine } \\
\text { yönelik tutum }\end{array}$} & $\begin{array}{l}\text { Equal variances } \\
\text { assumed }\end{array}$ & .460 & .498 & -.476 & 353 & .635 \\
\hline & $\begin{array}{l}\text { Equal variances } \\
\text { not assumed }\end{array}$ & & & -.436 & 12.767 & 670 \\
\hline
\end{tabular}


Din eğitimini diğer kaynaklardan alan öğrenciler ile DKAB dersi programının temel ilke ve hedeflerine yönelik tutumları arasında anlamlı bir ilişki yoktur.

Tablo 59

DKAB Dersi Programının Amacı, İçerik Ve Uygulanmasına Yönelik Tutumları İle Din Ĕ̆itimini Diğer Kaynaklardan Alan Öğrenciler Arasındaki İlişki

\begin{tabular}{|c|c|c|c|c|c|c|}
\hline & & \multicolumn{5}{|c|}{ Levene's Test for Equality of Variances } \\
\hline & & $\mathrm{F}$ & Sig. & $\mathrm{t}$ & df & $\begin{array}{l}\text { Sig. (2- } \\
\text { tailed) }\end{array}$ \\
\hline \multirow{2}{*}{$\begin{array}{l}\text { DKAB dersi } \\
\text { programının } \\
\text { amacı, içerik } \\
\text { ve } \\
\text { uygulanmasına } \\
\text { yönelik tutum }\end{array}$} & $\begin{array}{l}\text { Equal variances } \\
\text { assumed }\end{array}$ & .460 & .498 & -.476 & 353 & .635 \\
\hline & $\begin{array}{l}\text { Equal variances } \\
\text { not assumed }\end{array}$ & & & -.436 & 12.767 & .670 \\
\hline
\end{tabular}

Din eğitimini diğer kaynaklardan alan öğrenciler ile DKAB dersi programının amacı, içerik ve uygulanmasına yönelik tutumları arasında anlamlı bir ilişki yoktur.

Öğrencilerin din ile ilgili takip ettikleri kaynaklar ile tutum puanları arasındaki ilişki.

Tablo 60

Öğrencilerin Din İle İlgili Takip Ettikleri Kaynaklar

\begin{tabular}{|c|c|c|}
\hline \multirow{2}{*}{ Din ile ilgili aşağıdaki yayınlardan hangisini okursunuz ${ }^{1}$} & \multicolumn{2}{|c|}{ Evet } \\
\hline & $\mathrm{N}$ & $\%$ \\
\hline Dini Kitap & 132 & 37.2 \\
\hline Hiçbiri & 132 & 37.2 \\
\hline İlmihal Kitapları & 85 & 23.9 \\
\hline Diğer & 32 & 9.0 \\
\hline Dini dergi & 21 & 5.9 \\
\hline Gazete & 19 & 5.4 \\
\hline
\end{tabular}

\footnotetext{
${ }^{1}$ Birden fazla cevap vardır.

(C) 2018 AKU, Kuramsal Eğitimbilim Dergisi - Journal of Theoretical Educational Science, 11(4), 1019-1069
} 
Dini yayınları gazeteden takip eden öğrencileri ile tutumlar arasındaki ilişki. Dini yayınları gazeteden takip eden öğrenciler ile tutumlar arasındaki ilişkileri gösteren tablolar aşağıdaki gibidir:

Tablo 61

DKAB Dersine Yönelik Tutumları İle Dini Yayınları Gazeteden Takip Eden Öğrenciler Arasindaki İlişki

\begin{tabular}{lllllll}
\hline \multicolumn{5}{c}{} & \multicolumn{5}{c}{ Levene's Test for Equality of Variances } \\
\cline { 3 - 6 } & & $\mathrm{F}$ & $\mathrm{Sig}$. & $\mathrm{t}$ & $\mathrm{df}$ & Sig. (2-tailed) \\
\hline $\begin{array}{l}\text { DKAB } \\
\text { dersine } \\
\text { yönelik } \\
\text { tutum }\end{array}$ & $\begin{array}{l}\text { Equal variances } \\
\text { assumed }\end{array}$ & .057 & .811 & -.812 & 353 & .417 \\
\cline { 2 - 6 } & $\begin{array}{l}\text { Equal variances } \\
\text { not assumed }\end{array}$ & & & -.898 & 20.636 & .379 \\
\hline
\end{tabular}

Dini yayınları gazeteden takip eden öğrenciler ile DKAB dersine yönelik tutumları arasında anlamlı bir ilişki yoktur.

Tablo 62

DKAB Dersi Programının Yapısına Yönelik Tutumları İle Dini Yayınları Gazeteden Takip Eden Öğrenciler Arasındaki İlişki

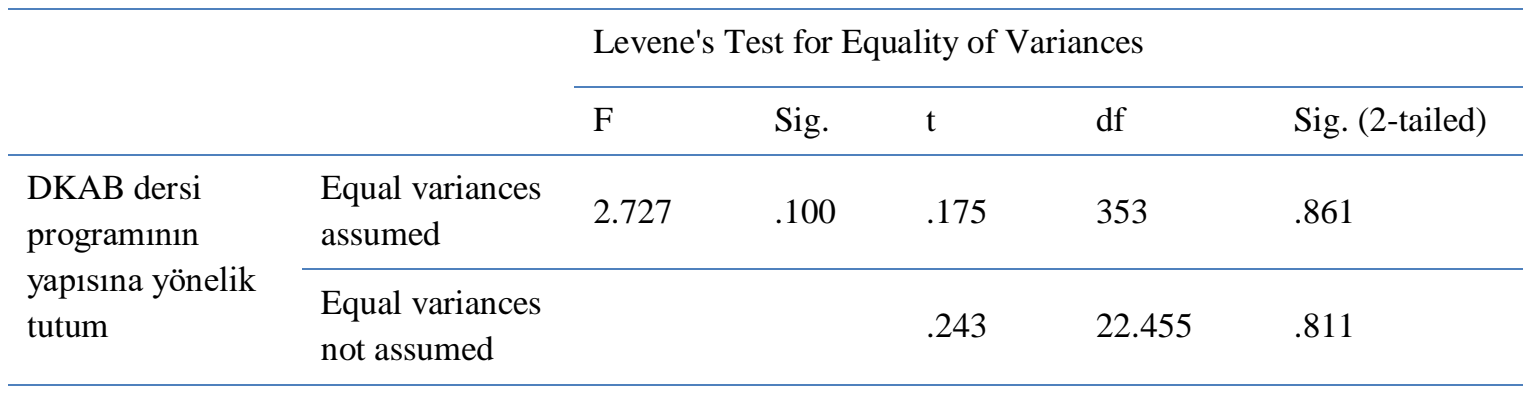

Dini yayınları gazeteden takip eden öğrenciler ile DKAB dersi programının yapısına yönelik tutumları arasında anlamlı bir ilişki yoktur.

Tablo 63

DKAB Dersi Programının Temel İlke Ve Hedeflerine Yönelik Tutumları İle Dini Yayınları Gazeteden Takip Eden Öğrenciler Arasındaki İlişki

\begin{tabular}{|c|c|c|c|c|c|c|}
\hline & & \multicolumn{5}{|c|}{ Levene's Test for Equality of Variances } \\
\hline & & $\mathrm{F}$ & Sig. & $\mathrm{t}$ & df & $\begin{array}{l}\text { Sig. (2- } \\
\text { tailed) }\end{array}$ \\
\hline \multirow{2}{*}{$\begin{array}{l}\text { DKAB dersi } \\
\text { programının } \\
\text { temel ilke ve } \\
\text { hedeflerine } \\
\text { yönelik tutum }\end{array}$} & $\begin{array}{l}\text { Equal variances } \\
\text { assumed }\end{array}$ & .489 & .485 & -.131 & 353 & .896 \\
\hline & $\begin{array}{l}\text { Equal variances } \\
\text { not assumed }\end{array}$ & & & -.158 & 21.240 & .876 \\
\hline
\end{tabular}


Dini yayınları gazeteden takip eden öğrenciler ile DKAB dersi programının temel ilke ve hedeflerine yönelik tutumları arasında anlamlı bir ilişki yoktur.

Tablo 64

DKAB Dersi Programının Amacı, Içerik Ve Uygulanmasına Yönelik Tutumları İle Dini Yayınları Gazeteden Takip Eden Öğrenciler Arasındaki İlişki

\begin{tabular}{|c|c|c|c|c|c|c|}
\hline & & \multicolumn{5}{|c|}{ Levene's Test for Equality of Variances } \\
\hline & & $\mathrm{F}$ & Sig. & $\mathrm{t}$ & $\mathrm{df}$ & $\begin{array}{l}\text { Sig. }(2- \\
\text { tailed })\end{array}$ \\
\hline \multirow{2}{*}{$\begin{array}{l}\text { DKAB dersi } \\
\text { programının } \\
\text { amacı, içerik ve } \\
\text { uygulanmasına } \\
\text { yönelik tutum }\end{array}$} & $\begin{array}{l}\text { Equal variances } \\
\text { assumed }\end{array}$ & .489 & .485 & -.131 & 353 & .896 \\
\hline & $\begin{array}{l}\text { Equal variances } \\
\text { not assumed }\end{array}$ & & & -.158 & 21.240 & .876 \\
\hline
\end{tabular}

Dini yayınları gazeteden takip eden öğrenciler ile DKAB dersi programının amacı, içerik ve uygulanmasına yönelik tutumları arasında anlamlı bir ilişki yoktur.

Tablolar incelendiğinde, dini yayınları gazeteden takip eden öğrencilerin sayısı çok düşüktür. $\mathrm{Bu}$ durum sağlıklı bir analiz yapılabilmesini engellemektedir. Yani karşılaştırma yapılan iki grubun katılımcıları arasında çok büyük fark vardır.

Dini yayınları dini kitaplardan takip eden öğrencileri ile tutumlar arasındaki ilişki. Dini yayınları dini kitaplardan takip eden öğrenciler ile tutumlar arasındaki ilişkileri gösteren tablolar aşağıdaki gibidir:

Tablo 65

DKAB Dersine Yönelik Tutumları İle Dini Yayınları Dini Kitaplardan Takip Eden Öğrenciler Arasındaki İlişki

\begin{tabular}{|c|c|c|c|c|c|c|}
\hline & & \multicolumn{5}{|c|}{ Levene's Test for Equality of Variances } \\
\hline & & $\mathrm{F}$ & Sig. & $\mathrm{t}$ & df & Sig. (2-tailed) \\
\hline \multirow{2}{*}{$\begin{array}{l}\text { DKAB } \\
\text { dersine } \\
\text { yönelik } \\
\text { tutum }\end{array}$} & $\begin{array}{l}\text { Equal variances } \\
\text { assumed }\end{array}$ & 1.507 & .220 & -5.561 & 353 & .000 \\
\hline & $\begin{array}{l}\text { Equal variances } \\
\text { not assumed }\end{array}$ & & & -5.647 & 288.330 & .000 \\
\hline
\end{tabular}


Dini yayınları dini kitaplardan takip eden öğrenciler ile DKAB dersine yönelik tutumları arasında anlamlı bir ilişki vardır. Dini yayınları dini kitaplardan takip eden öğrencilerin DKAB dersine yönelik tutumları, diğer öğrencilerin DKAB dersine yönelik tutumlarından anlamlı şekilde daha yüksektir.

Tablo 66

DKAB Dersi Programının Yapısına Yönelik Tutumlarl Ile Dini Yayınları Dini Kitaplardan Takip Eden Öğrenciler Arasındaki İlişki

\begin{tabular}{lllllll}
\hline & \multicolumn{5}{c}{ Levene's Test for Equality of Variances } \\
\cline { 2 - 6 } & & $\mathrm{F}$ & $\mathrm{Sig}$. & $\mathrm{t}$ & $\mathrm{df}$ & Sig. (2-tailed) \\
\hline $\begin{array}{l}\text { DKAB dersi } \\
\text { programinin } \\
\text { yapisina yönelik } \\
\text { tutum }\end{array}$ & $\begin{array}{l}\text { Equal variances } \\
\text { assumed }\end{array}$ & 1.366 & .243 & -4.537 & 353 & .000 \\
\cline { 2 - 6 } & $\begin{array}{l}\text { Equal variances } \\
\text { not assumed }\end{array}$ & & & -4.613 & 289.470 & .000 \\
\hline
\end{tabular}

Dini yayınları dini kitaplardan takip eden öğrenciler ile DKAB dersi programının yapısına yönelik tutumları arasında anlamlı bir ilişki vardır. Dini yayınları dini kitaplardan takip eden öğrencilerin DKAB dersi programının yapısına yönelik tutumları, diğer öğrencilerin $\mathrm{DKAB}$ dersi programının yapısına yönelik tutumlarından anlamlı şekilde daha yüksektir.

Tablo 67

DKAB Dersi Programının Temel İlke Ve Hedeflerine Yönelik Tutumları Ile Dini Yayınları Dini Kitaplardan Takip Eden Öğrenciler Arasındaki İlişki

\begin{tabular}{lllllll}
\hline & \multicolumn{5}{c}{ Levene's Test for Equality of Variances } \\
\cline { 3 - 6 } & & F & Sig. & t & df & $\begin{array}{c}\text { Sig. (2- } \\
\text { tailed) }\end{array}$ \\
\hline $\begin{array}{llllll}\text { DKAB dersi } \\
\text { programinin } \\
\text { temel ilke ve } \\
\text { hedeflerine } \\
\text { yönelik tutum }\end{array}$ & $\begin{array}{l}\text { Equal variances } \\
\text { assumed }\end{array}$ & 3.301 & .070 & -4.255 & 353 & .000 \\
\cline { 2 - 6 } & $\begin{array}{l}\text { Equal variances } \\
\text { not assumed }\end{array}$ & & & -4.394 & 302.764 & .000 \\
\hline
\end{tabular}

Dini yayınları dini kitaplardan takip eden öğrenciler ile DKAB dersi programının temel ilke ve hedeflerine yönelik tutumları arasında anlamlı bir ilişki vardır. Dini yayınları dini kitaplardan takip eden öğrencilerin DKAB dersi programının temel ilke ve hedeflerine yönelik tutumları, diğer öğrencilerin DKAB dersi programının temel ilke ve hedeflerine yönelik tutumlarından anlamlı şekilde daha yüksektir. 
Tablo 68

DKAB Dersi Programının Amacı, İçerik Ve Uygulanmasına Yönelik Tutumları İle Dini Yayınları Dini Kitaplardan Takip Eden Öğrenciler Arasındaki İlişki

\begin{tabular}{|c|c|c|c|c|c|c|}
\hline & & \multicolumn{5}{|c|}{ Levene's Test for Equality of Variances } \\
\hline & & $\mathrm{F}$ & Sig. & $\mathrm{t}$ & $\mathrm{df}$ & $\begin{array}{l}\text { Sig. (2- } \\
\text { tailed) }\end{array}$ \\
\hline \multirow{2}{*}{$\begin{array}{l}\text { DKAB dersi } \\
\text { programının } \\
\text { amacı, içerik ve } \\
\text { uygulanmasına } \\
\text { yönelik tutum }\end{array}$} & $\begin{array}{l}\text { Equal variances } \\
\text { assumed }\end{array}$ & 3.301 & .070 & -4.255 & 353 & .000 \\
\hline & $\begin{array}{l}\text { Equal variances } \\
\text { not assumed }\end{array}$ & & & -4.394 & 302.764 & .000 \\
\hline
\end{tabular}

Dini yayınları dini kitaplardan takip eden öğrenciler ile DKAB dersi programının amacı, içerik ve uygulanmasına yönelik tutumları arasında anlamlı bir ilişki vardır. Dini yayınları dini kitaplardan takip eden öğrencilerin DKAB dersi programının amacı, içerik ve uygulanmasına yönelik tutumları, diğer öğrencilerin DKAB dersi programının amacı, içerik ve uygulanmasına yönelik tutumlarından anlamlı şekilde daha yüksektir.

Dini yayınları dini dergilerden takip eden öğrencileri ile tutumlar arasındaki ilişki. Dini yayınları dini dergiden takip eden öğrenciler ile tutumlar arasındaki ilişkileri gösteren tablolar aşağıdaki gibidir:

Tablo 69

DKAB Dersine Yönelik Tutumları Ile Dini Yayınları Dini Dergiden Takip Eden Ö̆grenciler Arasındaki İlişki

\begin{tabular}{lllllll}
\hline \multicolumn{5}{c}{} & \multicolumn{5}{c}{ Levene's Test for Equality of Variances } \\
\cline { 3 - 6 } & & $\mathrm{F}$ & $\mathrm{Sig}$. & $\mathrm{t}$ & $\mathrm{df}$ & Sig. (2-tailed) \\
\hline $\begin{array}{l}\text { DKAB } \\
\text { dersine } \\
\begin{array}{l}\text { yönelik } \\
\text { tutum }\end{array}\end{array}$ & $\begin{array}{l}\text { Equal variances } \\
\text { assumed }\end{array}$ & 1.547 & .214 & -1.076 & 353 & .283 \\
\cline { 2 - 6 } & $\begin{array}{l}\text { Equal variances } \\
\text { not assumed }\end{array}$ & & & -.927 & 21.834 & .364 \\
\hline
\end{tabular}


Dini yayınları dini dergiden takip eden öğrenciler ile DKAB dersine yönelik tutumları arasında anlamlı bir ilişki yoktur.

Tablo 70

DKAB Dersi Programının Yapısına Yönelik Tutumları Ile Dini Yayınları Dini Dergiden Takip Eden Öğrenciler Arasındaki İlişki

\begin{tabular}{lllllll}
\hline & \multicolumn{5}{c}{ Levene's Test for Equality of Variances } \\
\cline { 2 - 6 } & & $\mathrm{F}$ & $\mathrm{Sig}$. & $\mathrm{t}$ & $\mathrm{df}$ & Sig. (2-tailed) \\
\hline $\begin{array}{llllll}\text { DKAB dersi } \\
\text { programının } \\
\text { yapisına yönelik } \\
\text { tutum }\end{array}$ & $\begin{array}{l}\text { Equal variances } \\
\text { assumed }\end{array}$ & .727 & .394 & -1.825 & 353 & .069 \\
\cline { 2 - 6 } & $\begin{array}{l}\text { Equal variances } \\
\text { not assumed }\end{array}$ & & & -1.850 & 22.670 & .077 \\
\hline
\end{tabular}

Dini yayınları dini dergiden takip eden öğrenciler ile DKAB dersi programının yapısına yönelik tutumları arasında anlamlı bir ilişki yoktur.

Tablo 71

DKAB Dersi Programının Temel Illke ve Hedeflerine Yönelik Tutumları İle Dini Yayınları Dini Dergiden Takip Eden Öğrenciler Arasındaki İlişki

\begin{tabular}{|c|c|c|c|c|c|c|}
\hline & & \multicolumn{5}{|c|}{ Levene's Test for Equality of Variances } \\
\hline & & $\mathrm{F}$ & Sig. & $\mathrm{t}$ & df & $\begin{array}{l}\text { Sig. (2- } \\
\text { tailed) }\end{array}$ \\
\hline \multirow{2}{*}{$\begin{array}{l}\text { DKAB dersi } \\
\text { programının } \\
\text { temel ilke ve } \\
\text { hedeflerine } \\
\text { yönelik tutum }\end{array}$} & $\begin{array}{l}\text { Equal variances } \\
\text { assumed }\end{array}$ & .381 & .538 & -1.031 & 353 & .303 \\
\hline & $\begin{array}{l}\text { Equal variances } \\
\text { not assumed }\end{array}$ & & & -.921 & 21.992 & .367 \\
\hline
\end{tabular}

Dini yayınları dini dergiden takip eden öğrenciler ile DKAB dersi programının temel ilke ve hedeflerine yönelik tutumları arasında anlamlı bir ilişki yoktur.

Tablo 72

DKAB Dersi Programının Amacı, İçerik ve Uygulanmasına Yönelik Tutumları İle Dini Yayınları Dini Dergiden Takip Eden Öğrenciler Arasındaki İlişki

\begin{tabular}{|c|c|c|c|c|c|c|}
\hline & & \multicolumn{5}{|c|}{ Levene's Test for Equality of Variances } \\
\hline & & $\mathrm{F}$ & Sig. & $\mathrm{t}$ & df & $\begin{array}{l}\text { Sig. (2- } \\
\text { tailed) }\end{array}$ \\
\hline \multirow{2}{*}{$\begin{array}{l}\text { DKAB dersi } \\
\text { programının } \\
\text { amacı, içerik ve } \\
\text { uygulanmasına } \\
\text { yönelik tutum }\end{array}$} & $\begin{array}{l}\text { Equal variances } \\
\text { assumed }\end{array}$ & .381 & .538 & -1.031 & 353 & .303 \\
\hline & $\begin{array}{l}\text { Equal variances } \\
\text { not assumed }\end{array}$ & & & -.921 & 21.992 & .367 \\
\hline
\end{tabular}


Dini yayınları dini dergiden takip eden öğrenciler ile DKAB dersi programının amacı, içerik ve uygulanmasına yönelik tutumları arasında anlamlı bir ilişki yoktur.

Tablolar incelendiğinde, dini yayınları dini dergiden takip eden öğrencilerin sayısı çok düşüktür. Bu durum sağlıklı bir analiz yapılabilmesini engellemektedir. Yani karşılaştırma yapılan iki grubun katılımcıları arasında çok büyük fark vardır.

Dini yayınları ilmihal kitaplardan takip eden öğrencileri ile tutumlar arasındaki ilişki. Dini yayınları ilmihal kitaplarından takip eden öğrenciler ile tutumlar arasındaki ilişkileri gösteren tablolar aşağıdaki gibidir:

Tablo 73

DKAB Dersine Yönelik Tutumları İle Dini Yayınları İlmihal Kitaplarından Takip Eden Öğrenciler Arasındaki İlişki

\begin{tabular}{|c|c|c|c|c|c|c|}
\hline & & \multicolumn{5}{|c|}{ Levene's Test for Equality of Variances } \\
\hline & & $\mathrm{F}$ & Sig. & $\mathrm{t}$ & $\mathrm{df}$ & Sig. (2-tailed) \\
\hline \multirow{2}{*}{$\begin{array}{l}\text { DKAB } \\
\text { dersine } \\
\text { yönelik } \\
\text { tutum }\end{array}$} & $\begin{array}{l}\text { Equal variances } \\
\text { assumed }\end{array}$ & 6.360 & .012 & -4.938 & 353 & .000 \\
\hline & $\begin{array}{l}\text { Equal variances } \\
\text { not assumed }\end{array}$ & & & -5.301 & 159.281 & .000 \\
\hline
\end{tabular}

Dini yayınları ilmihal kitaplarından takip eden öğrenciler ile DKAB dersine yönelik tutumları arasında anlamlı bir ilişki vardır. Dini yayınları dini kitaplardan takip eden öğrencilerin $\mathrm{DKAB}$ dersine yönelik tutumları, diğer öğrencilerin $\mathrm{DKAB}$ dersine yönelik tutumlarından anlamlı şekilde daha yüksektir.

Tablo 74

DKAB Dersi Programının Yapısına Yönelik Tutumları İe Dini Yayınları İlmihal Kitaplarından Takip Eden Öğrenciler Arasındaki İlişki

\begin{tabular}{lllllll}
\hline & \multicolumn{5}{c}{ Levene's Test for Equality of Variances } \\
\cline { 2 - 6 } & & $\mathrm{F}$ & $\mathrm{Sig}$. & $\mathrm{t}$ & $\mathrm{df}$ & Sig. (2-tailed) \\
\hline $\begin{array}{l}\text { DKAB dersi } \\
\text { programının } \\
\text { yapisına yönelik } \\
\text { tutum }\end{array}$ & $\begin{array}{l}\text { Equal variances } \\
\text { assumed }\end{array}$ & 3.611 & .058 & -4.351 & 353 & .000 \\
\cline { 2 - 6 } & $\begin{array}{l}\text { Equal variances } \\
\text { not assumed }\end{array}$ & & & -4.612 & 155.646 & .000 \\
\hline
\end{tabular}

Dini yayınları ilmihal kitaplarından takip eden öğrenciler ile DKAB dersi programının yapısına yönelik tutumları arasında anlamlı bir ilişki vardır. Dini yayınları ilmihal kitaplarından takip eden öğrencilerin DKAB dersi programının yapısına yönelik tutumları, diğer öğrencilerin $\mathrm{DKAB}$ dersi programının yapısına yönelik tutumlarından anlamlı şekilde daha yüksektir. 
Tablo 75

DKAB Dersi Programının Temel Illke Ve Hedeflerine Yönelik Tutumları Ile Dini Yayınları İlmihal Kitaplarından Takip Eden Öğrenciler Arasındaki İlişki

\begin{tabular}{lllllll}
\hline & \multicolumn{5}{c}{ Levene's Test for Equality of Variances } \\
\cline { 3 - 6 } & & F & Sig. & t & df & $\begin{array}{l}\text { Sig. (2- } \\
\text { tailed) }\end{array}$ \\
\hline $\begin{array}{llllll}\text { DKAB dersi } \\
\text { programinin } \\
\text { temel ilke ve } \\
\text { hedeflerine } \\
\text { yönelik tutum }\end{array}$ & $\begin{array}{l}\text { Equal variances } \\
\text { assumed }\end{array}$ & 3.628 & .058 & -4.488 & 353 & .000 \\
\cline { 2 - 6 } & $\begin{array}{l}\text { Equal variances } \\
\text { not assumed }\end{array}$ & & & -4.744 & 154.839 & .000 \\
\hline
\end{tabular}

Dini yayınları ilmihal kitaplarından takip eden öğrenciler ile DKAB dersi programının temel ilke ve hedeflerine yönelik tutumları arasında anlamlı bir ilişki vardır. Dini yayınları ilmihal kitaplarından takip eden öğrencilerin DKAB dersi programının temel ilke ve hedeflerine yönelik tutumları, diğer öğrencilerin DKAB dersi programının temel ilke ve hedeflerine yönelik tutumlarından anlamlı şekilde daha yüksektir.

Tablo 76

DKAB Dersi Programının Amacı, İçerik Ve Uygulanmasına Yönelik Tutumları İle Dini Yayınları İlmihal Kitaplarından Takip Eden Öğrenciler Arasındaki İlişki

\begin{tabular}{|c|c|c|c|c|c|c|}
\hline & & \multicolumn{5}{|c|}{ Levene's Test for Equality of Variances } \\
\hline & & $\mathrm{F}$ & Sig. & $\mathrm{t}$ & $\mathrm{df}$ & $\begin{array}{l}\text { Sig. }(2- \\
\text { tailed) }\end{array}$ \\
\hline \multirow{2}{*}{$\begin{array}{l}\text { DKAB dersi } \\
\text { programının } \\
\text { amacı, içerik ve } \\
\text { uygulanmasına } \\
\text { yönelik tutum }\end{array}$} & $\begin{array}{l}\text { Equal variances } \\
\text { assumed }\end{array}$ & 3.628 & .058 & -4.488 & 353 & .000 \\
\hline & $\begin{array}{l}\text { Equal variances } \\
\text { not assumed }\end{array}$ & & & -4.744 & 154.839 & .000 \\
\hline
\end{tabular}

Dini yayınları ilmihal kitaplarından takip eden öğrenciler ile DKAB dersi programının amacı, içerik ve uygulanmasına yönelik tutumları arasında anlamlı bir ilişki vardır. Dini yayınları ilmihal kitaplarından takip eden öğrencilerin DKAB dersi programının amacı, içerik ve uygulanmasına yönelik tutumları, diğer öğrencilerin DKAB dersi programının amacı, içerik ve uygulanmasına yönelik tutumlarından anlamlı şekilde daha yüksektir. 
Dini yayınları takip etmeyen öğrencileri ile tutumlar arasındaki ilişki. Dini yayınları takip etmeyen öğrenciler ile tutumlar arasındaki ilişkileri gösteren tablolar aşağıdaki gibidir:

Tablo 77

DKAB Dersine Yönelik Tutumları İle Dini Yayınları Takip Etmeyen Öğrenciler Arasındaki İlişki

\begin{tabular}{lllllll}
\hline \multicolumn{5}{c}{} & \multicolumn{5}{c}{ Levene's Test for Equality of Variances } \\
\cline { 3 - 7 } & & $\mathrm{F}$ & $\mathrm{Sig}$. & $\mathrm{t}$ & $\mathrm{df}$ & Sig. (2-tailed) \\
\hline $\begin{array}{l}\text { DKAB } \\
\text { dersine } \\
\text { yönelik } \\
\text { tutum }\end{array}$ & $\begin{array}{l}\text { Equal variances } \\
\text { assumed }\end{array}$ & .558 & .456 & 5.676 & 353 & .000 \\
\cline { 2 - 6 } & $\begin{array}{l}\text { Equal variances } \\
\text { not assumed }\end{array}$ & & & 5.557 & 257.204 & .000 \\
\hline
\end{tabular}

Dini yayınları takip etmeyen öğrenciler ile DKAB dersine yönelik tutumları arasında anlamlı bir ilişki vardır. Dini yayınları takip etmeyen öğrencilerin DKAB dersine yönelik tutumları, diğer öğrencilerin DKAB dersine yönelik tutumlarından anlamlı şekilde daha düşüktür.

Tablo 78

DKAB Dersi Programının Yapısına Yönelik Tutumları İle Dini Yayınları Takip Etmeyen Ö̆̆renciler Arasındaki İlişki

\begin{tabular}{lllllll}
\hline & \multicolumn{5}{c}{ Levene's Test for Equality of Variances } \\
\cline { 2 - 6 } & & $\mathrm{F}$ & Sig. & $\mathrm{t}$ & $\mathrm{df}$ & Sig. (2-tailed) \\
\hline $\begin{array}{l}\text { DKAB dersi } \\
\text { programının }\end{array}$ & $\begin{array}{l}\text { Equal variances } \\
\text { assumed }\end{array}$ & .054 & .816 & 4.094 & 353 & .000 \\
\cline { 2 - 6 } $\begin{array}{l}\text { yapisina yönelik } \\
\text { tutum }\end{array}$ & $\begin{array}{l}\text { Equal variances } \\
\text { not assumed }\end{array}$ & & & 4.041 & 264.038 & .000 \\
\hline
\end{tabular}

Dini yayınları takip etmeyen öğrenciler ile DKAB dersi programının yapısına yönelik tutumları arasında anlamlı bir ilişki vardır. Dini yayınları takip etmeyen öğrencilerin DKAB dersi programının yapısına yönelik tutumları, diğer öğrencilerin DKAB dersi programının yapısına yönelik tutumlarından anlamlı şekilde daha düşüktür. 
Tablo 79

DKAB Dersi Programının Temel Illke ve Hedeflerine Yönelik Tutumlar Ile Dini Yayınları Takip Etmeyen Öğrenciler Arasındaki İlişki

\begin{tabular}{|c|c|c|c|c|c|c|}
\hline & & \multicolumn{5}{|c|}{ Levene's Test for Equality of Variances } \\
\hline & & $\mathrm{F}$ & Sig. & $\mathrm{t}$ & df & $\begin{array}{l}\text { Sig. (2- } \\
\text { tailed) }\end{array}$ \\
\hline \multirow{2}{*}{$\begin{array}{l}\text { DKAB dersi } \\
\text { programının } \\
\text { temel ilke ve } \\
\text { hedeflerine } \\
\text { yönelik tutum }\end{array}$} & $\begin{array}{l}\text { Equal variances } \\
\text { assumed }\end{array}$ & 1.177 & .279 & 4.191 & 353 & .000 \\
\hline & $\begin{array}{l}\text { Equal variances } \\
\text { not assumed }\end{array}$ & & & 4.065 & 249.625 & .000 \\
\hline
\end{tabular}

Dini yayınları takip etmeyen öğrenciler ile DKAB dersi programının temel ilke ve hedeflerine yönelik tutumları arasında anlamlı bir ilişki vardır. Dini yayınları takip etmeyen öğrencilerin DKAB dersi programının temel ilke ve hedeflerine yönelik tutumları, diğer öğrencilerin DKAB dersi programının temel ilke ve hedeflerine yönelik tutumlarından anlamlı şekilde daha düşüktür.

Tablo 80

DKAB Dersi Programının Amacı, İçerik Ve Uygulanmasına Yönelik Tutumları İle Dini Yayınları Takip Etmeyen Öğrenciler Arasındaki İlişki

\begin{tabular}{|c|c|c|c|c|c|c|}
\hline & & \multicolumn{5}{|c|}{ Levene's Test for Equality of Variances } \\
\hline & & $\mathrm{F}$ & Sig. & $\mathrm{t}$ & $\mathrm{df}$ & $\begin{array}{l}\text { Sig. (2- } \\
\text { tailed) }\end{array}$ \\
\hline \multirow{2}{*}{$\begin{array}{l}\text { DKAB dersi } \\
\text { programının } \\
\text { amacı, içerik ve } \\
\text { uygulanmasına } \\
\text { yönelik tutum }\end{array}$} & $\begin{array}{l}\text { Equal variances } \\
\text { assumed }\end{array}$ & 1.177 & .279 & 4.191 & 353 & .000 \\
\hline & $\begin{array}{l}\text { Equal variances } \\
\text { not assumed }\end{array}$ & & & 4.065 & 249.625 & .000 \\
\hline
\end{tabular}

Dini yayınları takip etmeyen öğrenciler ile DKAB dersi programının amac1, içerik ve uygulanmasına yönelik tutumları arasında anlamlı bir ilişki vardır. Dini yayınları takip etmeyen öğrencilerin DKAB dersi programının amacı, içerik ve uygulanmasına yönelik tutumları, diğer öğrencilerin DKAB dersi programının amac1, içerik ve uygulanmasına yönelik tutumlarından anlamlı şekilde daha düşüktür. 
Dini yayınları diğer kaynaklardan takip eden öğrencileri ile tutumlar arasındaki ilişki. Dini yayınları diğer kaynaklardan takip eden öğrenciler ile tutumlar arasındaki ilişkileri gösteren tablolar aşağıdaki gibidir:

Tablo 81

DKAB Dersine Yönelik Tutumları İle Dini Yayınları Diğer Kaynaklardan Takip Eden Öğrenciler Arasındaki İlişki

\begin{tabular}{|c|c|c|c|c|c|c|}
\hline & & \multicolumn{5}{|c|}{ Levene's Test for Equality of Variances } \\
\hline & & $\mathrm{F}$ & Sig. & $\mathrm{t}$ & $\mathrm{df}$ & Sig. (2-tailed) \\
\hline \multirow{2}{*}{$\begin{array}{l}\text { DKAB } \\
\text { dersine } \\
\text { yönelik } \\
\text { tutum }\end{array}$} & $\begin{array}{l}\text { Equal variances } \\
\text { assumed }\end{array}$ & .570 & .451 & 2.436 & 353 & .015 \\
\hline & $\begin{array}{l}\text { Equal variances } \\
\text { not assumed }\end{array}$ & & & 2.263 & 36.320 & .030 \\
\hline
\end{tabular}

Dini yayınları diğer kaynaklardan takip eden öğrenciler ile DKAB dersine yönelik tutumları arasında anlamlıya yakın bir ilişki vardır. Dini yayınları diğer kaynaklardan takip eden öğrencilerin DKAB dersine yönelik tutumları, diğer öğrencilerin DKAB dersine yönelik tutumlarından daha düşüktür.

Tablo 82

DKAB Dersi Programının Yapısına Yönelik Tutumları İle Dini Yayınları Diğer Kaynaklardan Takip Eden Öğrenciler Arasındaki İlişki

\begin{tabular}{lllllll}
\hline & \multicolumn{5}{c}{ Levene's Test for Equality of Variances } \\
\cline { 2 - 6 } & & $\mathrm{F}$ & $\mathrm{Sig}$. & $\mathrm{t}$ & $\mathrm{df}$ & Sig. (2-tailed) \\
\hline $\begin{array}{l}\text { DKAB dersi } \\
\text { programının } \\
\text { yapisına yönelik } \\
\text { tutum }\end{array}$ & $\begin{array}{l}\text { Equal variances } \\
\text { assumed }\end{array}$ & .680 & .410 & 2.908 & 353 & .004 \\
\cline { 2 - 6 } & $\begin{array}{l}\text { Equal variances } \\
\text { not assumed }\end{array}$ & & & 2.664 & 36.138 & .011 \\
\hline
\end{tabular}

Dini yayınları diğer kaynaklardan takip eden öğrenciler ile DKAB dersi programının yapısına yönelik tutumları arasında anlamlı bir ilişki vardır. Dini yayınları diğer kaynaklardan takip eden öğrencilerin DKAB dersi programının yapısına yönelik tutumları, diğer öğrencilerin $\mathrm{DKAB}$ dersi programının yapısına yönelik tutumlarından anlamlı bir şekilde daha düşüktür. 
Tablo 83

DKAB Dersi Programının Temel Illke ve Hedeflerine Yönelik Tutumlar Ile Dini Yayınları Diğer Kaynaklardan Takip Eden Öğrenciler Arasındaki İlişki

\begin{tabular}{|c|c|c|c|c|c|c|}
\hline & & \multicolumn{5}{|c|}{ Levene's Test for Equality of Variances } \\
\hline & & $\mathrm{F}$ & Sig. & $\mathrm{t}$ & df & $\begin{array}{l}\text { Sig. (2- } \\
\text { tailed) }\end{array}$ \\
\hline \multirow{2}{*}{$\begin{array}{l}\text { DKAB dersi } \\
\text { programının } \\
\text { temel ilke ve } \\
\text { hedeflerine } \\
\text { yönelik tutum }\end{array}$} & $\begin{array}{l}\text { Equal variances } \\
\text { assumed }\end{array}$ & .868 & .352 & 2.324 & 353 & .021 \\
\hline & $\begin{array}{l}\text { Equal variances } \\
\text { not assumed }\end{array}$ & & & 2.101 & 35.968 & .043 \\
\hline
\end{tabular}

Dini yayınları diğer kaynaklardan takip eden öğrenciler ile DKAB dersi programının temel ilke ve hedeflerine yönelik tutumları arasında anlamlı bir ilişki yoktur.

\section{Tablo 84}

DKAB Dersi Programının Amacı, İçerik ve Uygulanmasına Yönelik Tutumları İle Dini Yayınları Diğer Kaynaklardan Takip Eden Öğrenciler Arasındaki İlişki

\begin{tabular}{|c|c|c|c|c|c|c|}
\hline & & \multicolumn{5}{|c|}{ Levene's Test for Equality of Variances } \\
\hline & & $\mathrm{F}$ & Sig. & $\mathrm{t}$ & df & $\begin{array}{l}\text { Sig. (2- } \\
\text { tailed) }\end{array}$ \\
\hline \multirow{2}{*}{$\begin{array}{l}\text { DKAB dersi } \\
\text { programının } \\
\text { amacı, içerik ve } \\
\text { uygulanmasına } \\
\text { yönelik tutum }\end{array}$} & $\begin{array}{l}\text { Equal variances } \\
\text { assumed }\end{array}$ & .868 & .352 & 2.324 & 353 & .021 \\
\hline & $\begin{array}{l}\text { Equal variances } \\
\text { not assumed }\end{array}$ & & & 2.101 & 35.968 & .043 \\
\hline
\end{tabular}

Dini yayınları diğer kaynaklardan takip eden öğrenciler ile DKAB dersi programının amacı, içerik ve uygulanmasına yönelik tutumları arasında anlamlı bir ilişki yoktur.

Tablolar incelendiğinde, dini yayınları diğer kaynaklardan takip eden öğrencilerin sayısı çok düşüktür. $\mathrm{Bu}$ durum sağlıklı bir analiz yapılabilmesini engellemektedir. Yani karşılaştırma yapılan iki grubun katılımcıları arasında çok büyük fark vardır. Bu çerçevede, örneklem sayısı daha fazla olsa idi, anlamlı ilişkiler olabilirdi. 


\section{Boyutlar Arası İlişkiler}

Ölçeği oluşturan; DKAB dersine, DKAB dersi programının yapısına, DKAB dersi programının temel ilke ve hedeflerine, DKAB dersi programının amacı, içerik ve uygulamasına yönelik tutum ölçekleri arasındaki ilişkiyi gösteren tablo aşağıdaki gibidir:

Tablo 85

Ölçekler Arasındaki İlişki

\begin{tabular}{|c|c|c|c|c|c|}
\hline \multicolumn{6}{|c|}{ Correlations } \\
\hline & & $\begin{array}{l}\text { DKAB } \\
\text { dersine } \\
\text { yönelik } \\
\text { tutum }\end{array}$ & $\begin{array}{l}\text { DKAB dersi } \\
\text { programinin } \\
\text { yapisı }\end{array}$ & $\begin{array}{l}\text { DKAB dersi } \\
\text { programının } \\
\text { temel ilkeleri } \\
\text { ve hedefi }\end{array}$ & $\begin{array}{l}\text { DKAB dersi } \\
\text { programının } \\
\text { amacı, içerik } \\
\text { ve uygulama }\end{array}$ \\
\hline \multirow{3}{*}{ DKAB dersine yönelik tutum } & $\begin{array}{l}\text { Pearson } \\
\text { Correlation }\end{array}$ & 1 & $.786^{* *}$ & $.765^{* *}$ & $.765^{* *}$ \\
\hline & Sig. (2-tailed) & & .000 & .000 & .000 \\
\hline & $\mathrm{N}$ & 355 & 355 & 355 & 355 \\
\hline \multirow{3}{*}{$\begin{array}{l}\text { DKAB dersi programının } \\
\text { yapısına yönelik tutum }\end{array}$} & $\begin{array}{l}\text { Pearson } \\
\text { Correlation }\end{array}$ & $.786^{* *}$ & 1 & $.902^{* *}$ & $.826^{* *}$ \\
\hline & Sig. (2-tailed) & .000 & & .000 & .000 \\
\hline & $\mathrm{N}$ & 355 & 355 & 355 & 355 \\
\hline \multirow{3}{*}{$\begin{array}{l}\text { DKAB dersi programının } \\
\text { temel ilkeleri ve hedefine } \\
\text { yönelik tutum }\end{array}$} & $\begin{array}{l}\text { Pearson } \\
\text { Correlation }\end{array}$ & $.765^{* *}$ & $.902^{* *}$ & 1 & $.819^{* *}$ \\
\hline & Sig. (2-tailed) & .000 & .000 & & .000 \\
\hline & $\mathrm{N}$ & 355 & 355 & 355 & 355 \\
\hline \multirow{3}{*}{$\begin{array}{l}\text { DKAB dersi programının } \\
\text { amacı, içerik ve } \\
\text { uygulamasına yönelik tutum }\end{array}$} & $\begin{array}{l}\text { Pearson } \\
\text { Correlation }\end{array}$ & $.765^{* *}$ & $.826^{* *}$ & $.819^{* *}$ & 1 \\
\hline & Sig. (2-tailed) & .000 & .000 & .000 & \\
\hline & $\mathrm{N}$ & 355 & 355 & 355 & 355 \\
\hline
\end{tabular}

**. Correlation is significant at the 0.01 level (2-tailed).

Tüm ölçekler arasında anlamlı ve pozitif bir ilişki vardır. Yani DKAB dersine yönelik tutum arttıkça DKAB dersi programının yapısına, temel ilke ve hedeflerine ve amaç, içerik ve uygulamasına yönelik tutumları da yükselmektedir. DKAB dersi programının yapısına yönelik tutumları arttıkça DKAB dersine, DKAB dersi programının temel ilke ve hedeflerine, amaç, içerik ve uygulamasına yönelik tutumları da artmaktadır. DKAB dersi programının temel ilke ve hedeflerine yönelik tutumları arttıkça; DKAB dersine, DKAB dersi programının yapısına ve amaç, içerik ve uygulamasına yönelik tutumları da artmaktadır. DKAB dersi programının amaç, içerik ve uygulamasına yönelik tutumları arttıkça, DKAB dersine, DKAB dersi programının yapısına, ilke ve hedeflerine; amaç, içerik ve uygulamasına yönelik tutumları da artmaktadir. 


\section{Sonuç ve Tartışma}

Eğitim topluma yön veren kurumlardan birisidir. Eğitimin topluma etkisi ve topluma yön verme derecesi, öncelikle eğitim programlarının toplumsal beklentilere uygun olarak hazırlanmasına ve sağlıklı işlemesine bağlıdır. Eğitim programlarının topluma etkisi, yön vermesi ve sosyal ihtiyaçlara cevap verebilmesi toplumun gereksinimlerinin analiz edilmesini gerektirir. Etkili bir din öğretimi için, program geliştirme sürecinde toplumun ihtiyacı bağlamında öğrenci beklentilerinin saptanması gerekmektedir.

$\mathrm{Bu}$ çalışmada ortaöğretim öğrencilerinin $\mathrm{DKAB}$ dersi ve programına yönelik tutumlarını ölçen bir ölçek geliştirilmiştir. Ölçeğin geçerlik ve güvenirlik testi yapılmıştır. Ölçeğin güvenirlik testi sonuçları bir boyutta iyi, diğer boyutlarda mükemmel kategorisinde çıkmıştır. Bu da geliştirdiğimiz ölçeğin ölçmek istediğimiz tutumları ölçmekte yeterli ve güvenli olduğunu göstermiştir. Ayrıca ölçek alanda güvenle kullanılmaya müsaittir. Bu açıdan alana katkı sağlayacaktır.

Öğrencilerin DKAB dersi ve programına yönelik tutumlarını etkileyen faktörler belirlenmiştir. $\mathrm{Bu}$ çerçevede araştırmamızın denenceleri test edilmiş ve aşağıdaki sonuçlara ulaşılmıştır. Ayrıca elde edilen sonuçlar benzer araştırmalar ile ilişkilendirilmiştir.

- Öğrencilerin Din Kültürü ve Ahlak Bilgisi dersine yönelik tutumları yüksektir ve öğrencilerin DKAB dersi ve programına yönelik tutumları cinsiyetlerine göre farklılaşmamaktadır. Kaya'nın (2001) ilköğretim ve lise, Arıcı'nın (2008) ise ilköğretim 6. ve 7. sinıflar üzerinde yaptığı araştırmalarda cinsiyet değişkeni açısından öğrencilerin DKAB dersine yönelik tutumlarında anlamlı bir farklılık tespit edilmemiştir. Zengin' in (2013) ilk ve ortaöğretim düzeyinde yaptığ araştırmada ise cinsiyet değişken açısından anlamlı bir ilişki tespit edilmiştir.

- Öğrencilerin DKAB dersi ve programına yönelik tutumları yaşlarına göre farklılaşmaktadır. Kaya'nın (2001) araştırmasında da okul kademesine göre ögrencilerin DKAB dersine karşı tutumunda anlamlı farklılık tespit edilmiştir. Araştırmada ilköğretim öğrencilerinin DKAB dersine karşı tutumu ortaöğretim öğrencilerinden daha yüksektir. Zengin'in (2013) araştırmasında da 4.sınıf öğrencilerinin DKAB dersine yönelik tutumları daha yüksek iken, 12. sınıf öğrencilerin tutum puanları daha düşük çıkmıştır. Bu da bizim araştırmamızdaki yaş büyüdükçe öğrencilerin $\mathrm{DKAB}$ dersine yönelik tutum puanlarının azalması sonucu ile örtüşmektedir.

- Öğrencilerin DKAB dersi ve programına yönelik tutumları sınıflarına göre farklılaşmaktadır. Kaya'nın (2001) araştırmasında okul kademesine göre öğrencilerin DKAB dersine karşı tutumunda anlamlı farklılık tespit edilmiştir. Araştırmada ilköğretim öğrencilerinin DKAB dersine karşı tutumu ortaöğretim öğrencilerinden daha yüksektir. Zengin'in (2013) araştırmasında da 4.sınıf öğrencilerinin DKAB dersine yönelik tutumları daha yüksek iken, 12. sınıf öğrencilerin tutum puanları daha düşük çıkmıştır. Bu durum bu araştırmalardaki bulgular ile ismi geçen araştırmacıların bulguları arasında paralellik olduğu anlamına gelmektedir

- Öğrencilerin DKAB dersi ve programına yönelik tutumları hayatlarının büyük çoğunluğunu geçirdikleri yere göre farklılaşmaktadır. Zengin (2013) de 
araştırmasında öğrencilerin yerleşim yerlerine göre $\mathrm{DKAB}$ dersine yönelik tutumlarında anlamlı farklılıklar tespit etmiştir. Araştırmaya göre köyde ikamet eden öğrencilerin $\mathrm{DKAB}$ dersine yönelik tutum düzeyleri diğer yerleşim yerlerinde ikamet edenlerden daha yüksektir. İl merkezlerinde DKAB dersine karşı olumlu tutum diğer yerleşim yerlerine göre daha azdır. Kaya'nın (2001) araştırmasında da köyde ikamet edenlerin tutum puanlan diğer yerleşim yerlerinde oturanlardan daha fazla çıkmıştır. Onun araştırma sonuçlarına göre ise en düşük tutum puanına kasaba-ilçede oturan öğrenciler sahip gözükmektedir. $\mathrm{Bu}$ durum bu araştırmalardaki bulgular ile ismi geçen araştırmacıların bulguları arasında paralellik olduğu anlamına gelmektedir.

- Öğrencilerin DKAB dersi ve programına yönelik tutumları din eğitimini aldıkları kaynaklara göre farklılaşmaktadır. Zengin'in (2013) araştırmasında DKAB dersi almadan önce ailede veya camide din eğitimi alma durumunun öğrenci tutumlarını anlamlı düzeyde etkilediği görülmektedir. Buna göre ailede ve camide daha önce eğitim almış öğrencilerin DKAB dersine yönelik tutumları, almayanlara göre daha yüksektir. bu durum bu araştırma ile Zengin'in araştırması arasındaki paralelliği göstermektedir.

- Öğrencilerin DKAB dersi ve programına yönelik tutumları dini yayınları takip ettikleri kaynaklara göre farklılaşmaktadır.

- Öğrencilerin DKAB dersine yönelik tutumları ile DKAB dersi programının yapısına, DKAB dersi programının temel ilke ve hedeflerine, DKAB dersi programının amaç, içerik ve uygulamasına yönelik tutumları arasında anlamlı ve pozitif bir ilişki vardır.

- Öğrencilerin DKAB dersi programının yapısına yönelik tutumları ile DKAB dersine, DKAB dersi programının temel ilke ve hedeflerine, DKAB dersi programının amaç, içerik ve uygulamasına yönelik tutumları arasında anlamlı ve pozitif bir ilişki vardır.

- Öğrencilerin DKAB dersi programının temel ilke ve hedeflerine yönelik tutumları ile DKAB dersine, DKAB dersi programının yapısına ve DKAB dersi programının amaç, içerik ve uygulamasına yönelik tutumları arasında anlamlı ve pozitif bir ilişki vardır.

- Öğrencilerin DKAB dersi programının amaç, içerik ve uygulamasına yönelik tutumları ile DKAB dersine, DKAB dersi programının yapısına, DKAB dersi programının temel ilke ve hedeflerine yönelik tutumları arasında anlamlı ve pozitif bir ilişki vardır. 


\section{Summary}

Purpose and Significance: Education is one of the institutions that direct society. The impact of education on society and the degree to which society directs primarily depends on the preparation and proper functioning of educational programs in line with social expectations. Developments in science and technology are rapidly changing the structure of societies. As a result of these changes different human power is needed. For this reason, education programs have to develop themselves to raise individuals who are qualified by societies. The effort to keep up with these changes makes it inevitable to create an education system that allows to follow innovations and open to developments.

Effective religious education is possible by meeting the expectations of the students and responding to their interests and needs.

The main problem of our research is as follows: What is the attitude of high school students towards the program of Religious Culture and Morality? And what are the factors affecting these attitudes? For this reason, I developed a scale to answer these questions.

Method: In this research, quantitative research method was used to determine the attitudes of the students towards the Religious Culture and Moral Knowledge course, the structural features of this course program, and its basic principles and objectives, purpose, content and application. It also aims to determine whether or not these attitudes differ according to the factors.

The dependent variables of the research are: The attitudes of the students towards Religious Culture and Moral Knowledge and their attitudes towards the structural features of the program and their attitudes towards its basic principles and objectives, their attitudes towards its purpose, content and application. The independent variables of the research are: The status of the students in terms of gender, age, class, the place where they spend most of their lives, where they get religious education, and follow religious publications.

Results: The research yielded the following results:

- Students 'attitudes towards Religious Culture and Moral Knowledge (RCMK) course are high and students' attitudes towards RCMK course and program do not differ according to their gender.

- Students' attitudes towards the RCMK course and program vary according to their age.

- Students' attitudes towards the RCMK course and program vary according to their grade.

- Students' attitudes towards the RCMK course and program differ according to the place they spend most of their lives.

- Students' attitudes towards the RCMK course and program differ according to the sources of religious education.

- Students' attitudes towards the RCMK course and program differ in terms of religious publications and the sources they follow. 
- There is a significant and positive relationship between the attitudes of the students towards the course of the RCMK course and the structure of the course program, its basic principles and objectives, and the attitudes towards the purpose, content and application of the program.

- There is a significant and positive relationship between the attitudes of the students towards the structure of the RCMK course program and the attitudes towards the course and its main principles and objectives and its purpose, content and application.

- There is a significant and positive relationship between the attitudes of the students towards the basic principles and objectives of the RCMK course and the attitudes towards RCMK course, the structure of the RCMK course program and the purpose, content and application of the RCMK course program.

- There is a significant and positive relationship between the attitudes of students towards the purpose, content and application of the RCMK, and the attitudes towards the RCMK course and the structure of the RCMK course program and the basic principles and objectives of the RCMK course program. 


\section{Kaynakça}

Altaş, N. (2008). İlköğretim öğrencilerinin din öğretimi sürecinde ilgi duydukları konular (Ankara ili örneğinde 6, 7 ve 8. sınıf öğrencileri üzerinde karşılaştırmalı bir analiz). Ankara Üniversitesi İlahiyat Fakültesi Dergisi, 49(II), 103-120.

Arıcı, İ. (2008). Öğrencilerin cinsiyetlerinin ilköğretim din kültürü ve ahlak bilgisi dersindeki başarı düzeylerine etkisi. Firat Üniversitesi Ilahiyat Fakültesi Dergisi, 13(1), 161-175.

Balc1, A. (2001). Sosyal bilimlerde araştırma-yöntem, teknik ve ilkeler (3. Bask1). Ankara: Pegem Akademi Yayıncılık.

Celep, C. ve Bülbül, T. ve Tunç, B. (2000). Aday öğretmenlerin atanma odakları. Trabzon VIII. Ulusal Eğitim Bilimleri Kongresi Bilimsel Çalışmaları, 1, 569-575.

Demirel, Ö., Seferoğlu, S., \& Yağc1, E. (2001). Öğretim teknolojileri ve materyal geliştirme. Ankara: Pegem Akademi Yayıncılık.

Ertürk, S. (1975). Eğitimde program geliştirme. Ankara: Yelkentepe Yayınları.

Gökçe, B. (1988). Toplumsal bilimlerde araştırma. Ankara: Savaş Yayınları.

Karasar, N. (1998). Bilimsel araştırma yöntemi. Ankara: Nobel Yayıncılık.

Kaya, M. (2001). İlköğretim ve ortaöğretim öğrencilerinin din kültürü ve ahlak bilgisi dersine karşı tutumları. Ondokuz Mayıs Üniversitesi İlahiyat Fakültesi Dergisi, 12, 43-78.

Milli Eğitim Bakanlığ1. (M.E.B). (2010). Ortaöğretim din kültürü ve ahlak bilgisi dersi $(9,10,11,12$. sinıflar) ögretim programı ve kılavuzu. Ankara.

Selçuk, M. (1998) Din eğitimi özgürleştiren bir süreç olabilir mi? İslamiyat, 1(1), 73-87.

Özdemir, M. \& Sönmez, S. (2000). Sinıf öğretmeni adaylarına öğretmen el kitabı. Ankara: Pegem Akademi Yayınları.

Tandoğan, M. (2001). Türkiye'de eğitim-insan yetiştirme- biliminin analizi. Eğitim Araştırmaları, 5, 93-95.

Tavşanc1l, E. (2014). Tutumların ölçülmesi ve SPSS ile veri analizi (5. Bask1). Ankara: Nobel Yayın Dağıtım.

Uçar, R. \& İpek, C. (2006). İlköğretim kurumlarında görev yapan yönetici ve öğretmenlerin MEB hizmetiçi eğitim uygulamalarına ilişkin görüşleri. Yüzüncü Yıl Üniversitesi Eğitim Fakültesi Dergisi, 6(1), 34-53.

Zengin, M. (2013). Öğrencilerin din kültürü ve ahlak bilgisi dersine yönelik tutumlarının çeşitli değişkenler açısından incelenmesi. Değerler Eğitimi Dergisi, 11(25), 271-301.

This is an Open Access article distributed under the terms of the Creative CommonsAttributionNonCommercial-ShareAlike 4.0 International (CC BY-NC-SA 4.0). For further information, you can refer to https://creativecommons.org/licenses/by-nc-sa/4.0/ 